Article

\title{
Synthesis of Lasofoxifene, Nafoxidine and Their Positional Isomers via the Novel Three-Component Coupling Reaction
}

\author{
Kenya Nakata, Yoshiyuki Sano and Isamu Shiina * \\ Department of Applied Chemistry, Faculty of Science, Tokyo University of Science, 1-3 Kagurazaka, \\ Shinjuku-ku, Tokyo 162-8601, Japan
}

* Author to whom correspondence should be addressed; E-Mail: shiina@rs.kagu.tus.ac.jp; Fax: +81-3-3260-5609.

Received: 21 August 2010; in revised form: 13 September 2010 / Accepted: 20 September 2010/ Published: 28 September 2010

\begin{abstract}
A Lewis acid-mediated three-component coupling reaction was successfully applied for the synthesis of lasofoxifene (1), nafoxidine (2), and their positional isomers, inv-lasofoxifene (3) and inv-nafoxidine (4). In the presence of $\mathrm{HfCl}_{4}$, the desired one-pot coupling reaction among 4-pivaloyloxybenzaldehyde (5), cinnamyltrimethylsilane (6), and anisole proceeded to afford the corresponding 3,4,4-triaryl-1-butene 7 in high yield. The iodocarbocyclization of the coupling product and the successive elimination of hydrogen iodide forming the olefin part, followed by the migration of the double-bond afforded the common synthetic intermediate of lasofoxifene (1) and nafoxidine (2) via a very concise procedure. Additionally, the syntheses of their positional isomers inv-lasofoxifene (3) and inv-nafoxidine (4) were also achieved through very convenient protocols.
\end{abstract}

Keywords: three-component coupling reaction; diversity oriented synthesis; lasofoxifene; nafoxidine; inv-lasofoxifene; inv-nafoxidine

\section{Introduction}

Multi-component coupling reactions (MCRs) are one of the most important tools in organic synthesis for the divergent production of bioactive molecules and highly complicated natural products [1-3]. In the beginning, the Strecker- and the Mannich-reactions were developed as three-component coupling reactions to form the corresponding $\alpha$-amino or $\beta$-amino acids, and a variety of biologically important compounds were prepared in a one-pot operation according to these useful procedures. After that, a 
more advanced four-segment coupling reaction was reported by Ugi et al. The Ugi-reaction directly forms various $\alpha$-amino acid derivatives from a mixture of primary amine, aldehyde, isonitrile, and carboxylic acid in one-pot, so that it was successfully utilized in the effective syntheses of a number of natural products and pharmaceutically valuable molecules [4,5]. Recent progress of synthetic organic chemistry has further established other kinds of MCRs that provide large-size oligosaccharides using sequential stereoselective glycosylations [6,7] or bioactive heterocyclic compounds starting from the conjugated organic molecules using transition-metal catalysts $[8,9]$.

We have also developed a novel and useful three-component coupling reaction among aromatic aldehydes, allylmetal reagents, and aromatic nucleophiles in the presence of a Lewis acid catalyst to afford 4,4-diaryl-1-butenes [10,11], which contain the basic skeleton of selective estrogen receptor modulators (SERMs, Figure 1) [12-15]. We further applied this methodology for the preparation of biologically active molecules, such as tamoxifen [16,17], droloxifene [17,18], lasofoxifene [19], nafoxidine [19], and pseudo-symmetric tamoxifen derivatives [20-22], etc. Related MCRs to form various substituted aromatic compounds were currently reported by other groups [23-26]. Herein, we present full results of the synthesis of lasofoxifene (1) and nafoxidine (2) as well as their positional isomers, inv-lasofoxifene (3) and inv-nafoxidine (4), to indicate further synthetic utilities of the novel three-component coupling reaction (Figure 2).

Figure 1. Structures of representive SERMs: tamoxifen, droloxifene, idoxifen, and raloxifene.

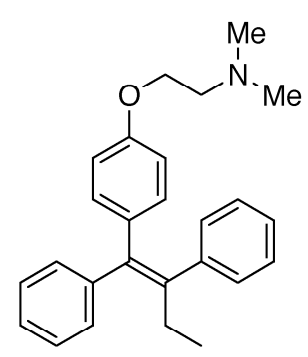

Tamoxifen (anti-tumor agent) breast cancer

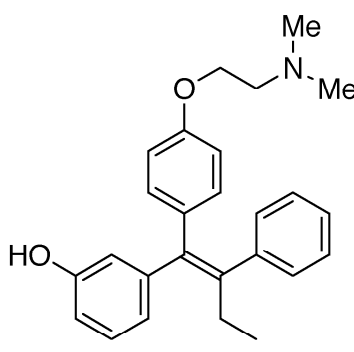

Droloxifene (anti-tumor agent) breast cancer

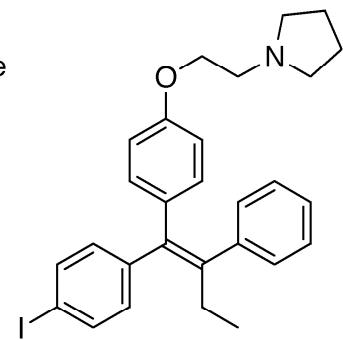

Idoxifen (anti-tumor agent) breast cancer

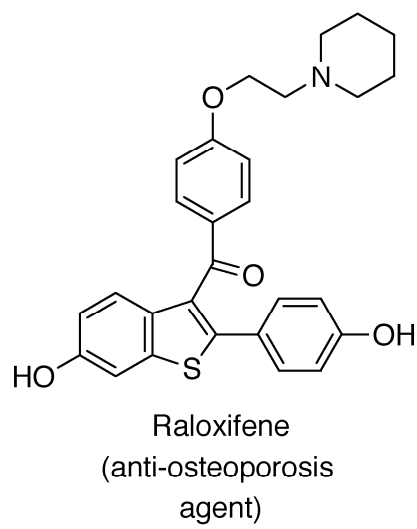

Figure 2. Structures of lasofoxifene (1) and nafoxidine (2) and their positional isomers (3) and (4).

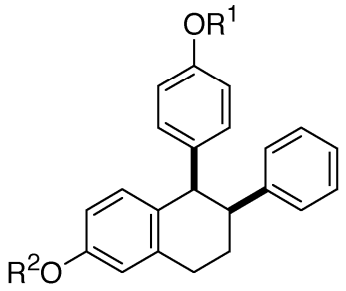

Lasofoxifene (1); $\mathrm{R}^{1}=\mathrm{CH}_{2} \mathrm{CH}_{2} \mathrm{~N}, \mathrm{R}^{2}=\mathrm{H}$ inv-Lasofoxifene (3); $\mathrm{R}^{1}=\mathrm{H}, \mathrm{R}^{2}=\mathrm{CH}_{2} \mathrm{CH}_{2} \mathrm{~N}$<smiles>Oc1ccc(C2=C(c3ccccc3)CCc3cc(O)ccc32)cc1</smiles>

Nafoxidine (2); $\mathrm{R}^{1}=\mathrm{CH}_{2} \mathrm{CH}_{2} \mathrm{~N}, \mathrm{R}^{2}=\mathrm{Me}$ inv-Nafoxidine (4); $\mathrm{R}^{1}=\mathrm{Me}, \mathrm{R}^{2}=\mathrm{CH}_{2} \mathrm{CH}_{2} \mathrm{~N}$ 
Lasofoxifene (1), discovered in 1996, is a new drug belonging to the third-generation SERMs and the current hopeful candidate for the treatment of osteoporosis, with clinical trials now in significant progress [27,28]. After observing the promising results of $\mathbf{1}$ on osteoporosis, a few improved methods for the preparation of $\mathbf{1}$ have been reported. As shown in the following examples, all protocols for the generation of lasofoxifene (1) utilized nafoxidine (2) or its derivative as a precursor of $\mathbf{1}$. It should be noted that 2 itself is also known as a SERM [29]. First, Lednicer et al. reported a method for the synthesis of $\mathbf{2}$ via the dehydration reaction of the tertiary alcohol, which was obtained by the reaction of an aromatic Grignard reagent with 2-phenyl-1-tetralone generated from a chalcone derivative [3033]. Cameron et al. at Pfizer, Inc., developed their original pathway to produce 1 and $\mathbf{2}$ via the Suzuki coupling between 1-aryl-2-bromo-3,4-dihydronaphthalene and phenylboronic acid [34,35]. The Chu group at Pfizer, Inc., also showed an alternative route to $\mathbf{1}$ and $\mathbf{2}$ via the intramolecular reductive coupling process of a diketone using low-valent titanium species to form the desired 1,2-diaryl-3,4dihydronaphthalene [36]. Due to all of these synthetic methods for the preparation of $\mathbf{1}$ and $\mathbf{2}$ requiring relatively longer routes to form the desired backbone of the targeted molecules, it is desirable to develop an improved and facile protocol for providing 2 using new technologies.

\section{Results and Discussion}

Our synthetic strategy of lasofoxifene (1) and nafoxidine (2) is outlined in Scheme 1. In our preliminary investigations of tamoxifen and its derivatives using the three-component coupling reaction [16-22], the obtained 3,4,4-triaryl-1-butene $\mathbf{A}$ was found to be the common skeleton of SERMs. It is anticipated that $\mathbf{A}$ would also be easily converted into a key intermediate as a precursor of 1 and 2. The terminal olefin part in A might be transformed into an iodonium ion intermediate, which could react with one of the two aromatic rings at the $\mathrm{C}-1$ position by electrophilic aromatic substitution to produce a cyclized structure $\mathbf{B}$.

After the elimination of hydrogen iodide, the generated double-bond could be migrated with a base to afford dihydronaphthalene structure $\mathbf{C}$, which corresponds to the main frames of $\mathbf{1}$ and $\mathbf{2}$. The successive installation of an appropriate side-chain into $\mathbf{C}$ might produce 2 . Since it is already known that $\mathbf{2}$ could be converted to $\mathbf{1}$ by hydrogenation of the double-bond as shown in the above instances, establishment of a method for the preparation of $\mathbf{2}$ would be equivalent to completion of the formal total synthesis of $\mathbf{1}$. According to this synthetic plan, we started to develop a new method for the preparation of $\mathbf{1}$ and $\mathbf{2}$ through the three-component coupling reaction as part of our continuous efforts applying this novel protocol to produce new types of SERMs.

2.1. Diversity Oriented Synthesis of the Common Frameworks of Lasofoxifene (1), Nafoxidine (2), invLasofoxifene (3), and inv-Nafoxidine (4) Using the Lewis acid-Mediated Three-Component Coupling Reaction

We first tried to optimize the reaction conditions of the three-component coupling process among 4-pivaloyloxybenzaldehyde (5), cinnamyltrimethylsilane (6), and anisole (Scheme 2). These results are summarized in Table 1. Anisole was used as a solvent in this reaction, therefore, the determination of the best concentrations of substrates $\mathbf{5}$ and $\mathbf{6}$ to anisole was crucially important to attain the satisfactory yield of the desired 3,4,4-triaryl-1-butene 7. Although the targeted molecule 7 was produced in 
medium yield $(43 \%)$ when the reaction was carried out at a low concentration $(0.1 \mathrm{M})$ in anisole including 1 molar amount of 5 and 1.2 molar amounts of 6 as shown in Entry 1, the yield of 7 increased to $63 \%$ by the reaction of 1 molar amount of 5 and 2 molar amounts of 6 at the same concentration of 5 in anisole (Entry 2). As shown in Entries 3-5, better results were obtained under the higher concentrations of 5 in anisole (0.3-0.4 M) and the coupling product 7 was obtained in good yield (72-79\%) using a two-fold amount of 6 to 5. On the other hand, the yield of the three-component coupling product 7 was lowered by rising the concentration of substrate 5 in anisole (Entries 6-8), because the amount of anisole as a second nucleophile in this reaction was inversely proportional to the concentration of 5 in anisole.

Scheme 1. Synthetic strategy for providing lasofoxifene (1) and nafoxidine (2).<smiles>[R]c1ccc(C=O)cc1</smiles>

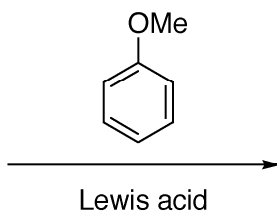

Three-component Coupling Reaction<smiles>[R]c1ccc(C(c2ccccc2)C(C=C)c2ccc(OC)cc2)cc1</smiles>

A

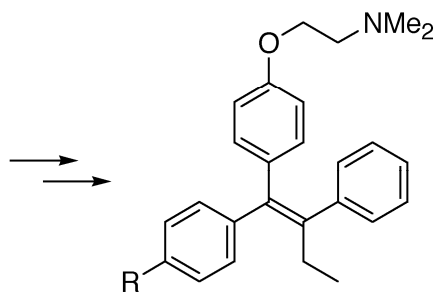

Tamoxifen; $\mathrm{R}=\mathrm{H}$<smiles>COc1ccc(C2C(C(=[I+])c3ccccc3)=C([I+])c3cc(P)ccc32)cc1</smiles>

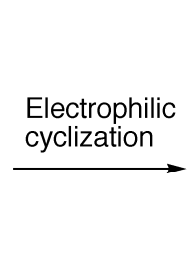<smiles>COc1ccc(C2c3ccc(P)cc3CC(I)C2c2ccccc2)cc1</smiles>

B

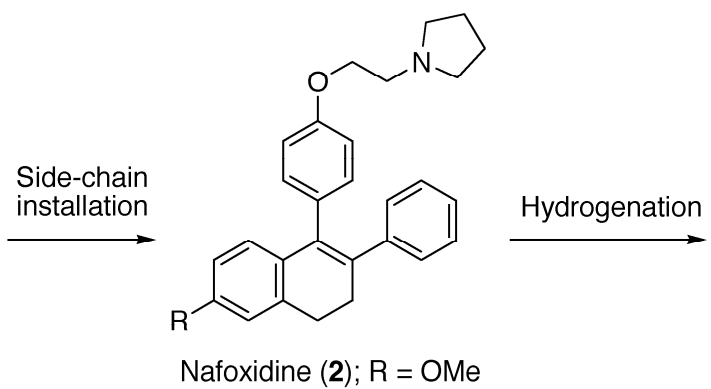<smiles>COc1ccc(C2=C(c3ccccc3)CCc3cc(P)ccc32)cc1</smiles>

C<smiles>[R]c1ccc2c(c1)CC[C@H](c1ccccc1)[C@H]2c1ccc(OCCN2CCCC2)cc1</smiles>

Lasofoxifene (1); $\mathrm{R}=\mathrm{OH}$

Scheme 2. The three-component coupling reaction among 4-pivaloyloxybenzaldehyde (5), cinnamyltrimethylsilane (6), and anisole in the presence of $\mathrm{HfCl}_{4}$.<smiles>CCCOc1ccc(C=O)cc1</smiles>

6

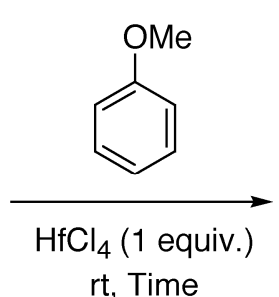

rt, Time<smiles>C=CC(c1ccccc1)[C@H](c1ccc(OC)cc1)c1ccc(OCCC)cc1</smiles>

7 
Table 1. Synthesis of 3,4,4-triaryl-1-butene 7 by the three-component coupling reaction among 4-pivaloyloxybenzaldehyde (5), cinnamyltrimethylsilane (6), and anisole in the presence of $\mathrm{HfCl}_{4}{ }^{a}$

\begin{tabular}{|l|l|l|l|l|}
\hline Entry & $\mathbf{5 / 6}$ (equiv.) & Conc. $(\mathrm{mol} / \mathrm{L})$ & Time $(\mathrm{h})$ & Yield of $\mathbf{7}(\%) b$ \\
\hline 1 & $1 / 1.2$ & 0.1 & 20 & 43 \\
\hline 2 & $1 / 2$ & 0.1 & 20 & 63 \\
\hline 3 & $1 / 2$ & 0.3 & 1 & 79 \\
\hline 4 & $1 / 2$ & 0.3 & 2 & 78 \\
\hline 5 & $1 / 2$ & 0.4 & 2 & 72 \\
\hline 6 & $1 / 2$ & 0.6 & 20 & 67 \\
\hline 7 & $1 / 2$ & 0.7 & 20 & 56 \\
\hline 8 & $1 / 2$ & 0.8 & 20 & 54 \\
\hline
\end{tabular}

a All new compounds were characterized by ${ }^{1} \mathrm{H}$ NMR, ${ }^{13} \mathrm{C}$ NMR spectroscopy and mass spectroscopy. ${ }^{b}$ Isolated yields after purification by silica gel chromatography.

All of the coupling reactions listed in Table 1 afforded $c a$ a 3:2 mixture of the anti-(3SR,4RS)- and syn-(3RS,4RS)-diastereomers of the 3,4,4-triaryl-1-butene. The ratio of the diastereomers was determined by ${ }^{1} \mathrm{H}-\mathrm{NMR}$ and HPLC analyses. Because these compounds could not be separated at this stage, a diastereomeric mixture of the coupling products was used for the next carbocyclization step without further purification. It was anticipated that both compounds might be converted into the corresponding valuable dihydronaphthalene derivatives by the double-bond migration in the later step.

Secondly, several methods for the electrophilic cyclization to form the fused compounds 8 and 9 from 3,4,4-triaryl-1-butene 7 were examined (Scheme 3). No transformation occurred when the $\mathrm{BF}_{3} \cdot \mathrm{OEt}_{2}$-mediated reaction was first applied for the ring closure reaction of 7 according to the literature method [37,38], and the bromine-mediate carbocyclization procedure using $\mathrm{NBS} / \mathrm{BF}_{3} \cdot \mathrm{OEt}_{2}$ at $-78{ }^{\circ} \mathrm{C}$ resulted in a rather complicated reaction mixture. We next tried the iodine-induced cationic cyclization of 7 using bis(pyridine)iodonium(I) tetrafluoroborate $\left(\mathrm{I}(\mathrm{py})_{2} \mathrm{BF}_{4}\right)$, which was developed by Barluenga [39,40] and Casey [41]. Fortunately, the desired cyclization smoothly took place in the presence of stoichiometric amounts of $\mathrm{I}(\mathrm{py})_{2} \mathrm{BF}_{4} / \mathrm{BF}_{3} \cdot \mathrm{OEt}_{2}$, and two bicyclic products 8 and 9 were predominantly obtained in $41 \%$ and $27 \%$ yields, respectively. We further applied bis(2,4,6trimethylpyridine)iodonium(I) hexafluorophosphate (I(collidine) ${ }_{2} \mathrm{PF}_{6}$ ), which was used as electrophilic halogenation reagent by Rousseau [42], for the cyclization of 7 and the reaction also smoothly proceeded to produce 8 and $\mathbf{9}$ in 45 and 30\%, respectively. It is noteworthy that both cyclized compounds $\mathbf{8}$ and $\mathbf{9}$ have all trans configurations and the reaction exclusively afforded these positional isomers 8 and $\mathbf{9}$.

The primary structures of the two cyclized compounds 8 and $\mathbf{9}$ listed above were confirmed by the observation of the enhanced NOEs of these products as illustrated in Figure $\mathbf{3}$ and the positions of the methoxy and pivaloyloxy groups on the aromatic rings have been unambiguously determined. Furthermore, relative stereochemistries of these positional isomers were definitely deduced on the basis of the coupling constants of the ${ }^{1} \mathrm{H}-\mathrm{NMR}$ spectroscopy. 
Scheme 3. Iodine-induced cationic carbocyclization of the coupling product 7 .<smiles>C=CC(c1ccccc1)C(c1ccc(OC)cc1)c1ccc(OC(C)C)cc1</smiles>

7

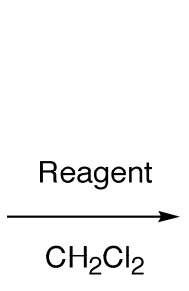

$(3 S R, 4 R S):(3 R S, 4 R S)=$ ca $3: 2$<smiles>COc1ccc([C@@H]2c3ccc(OC)cc3C[C@H](I)[C@H]2c2ccccc2)cc1</smiles>

8<smiles>CCCOc1ccc2c(c1)CC(I)[C@@H](c1ccccc1)[C@H]2c1ccc(OC)cc1</smiles>

9

Reagent (equiv.) and conditions;

$\mathrm{I}(\mathrm{py})_{2} \mathrm{BF}_{4}(1.3) / \mathrm{BF}_{3} \cdot \mathrm{OEt}_{2}(0.7) ; \quad-78{ }^{\circ} \mathrm{C}, 2 \mathrm{~h}$, Yield $[8 ; 9]=41 ; 27(\%)$

I(collidine) $)_{2} \mathrm{PF}_{6}(1.2) / \mathrm{BF}_{3} \cdot \mathrm{OEt}_{2}(2.4) ;-78{ }^{\circ} \mathrm{C}$ to $\mathrm{rt}, 18 \mathrm{~h}$, Yield $[\mathbf{8} ; 9]=45 ; 30(\%)$

Figure 3. Determination of the positions of methoxy and pivaloyloxy groups in $\mathbf{8}$ and $\mathbf{9}$ and the stereochemistry of $\mathbf{8}$ and $\mathbf{9}$.

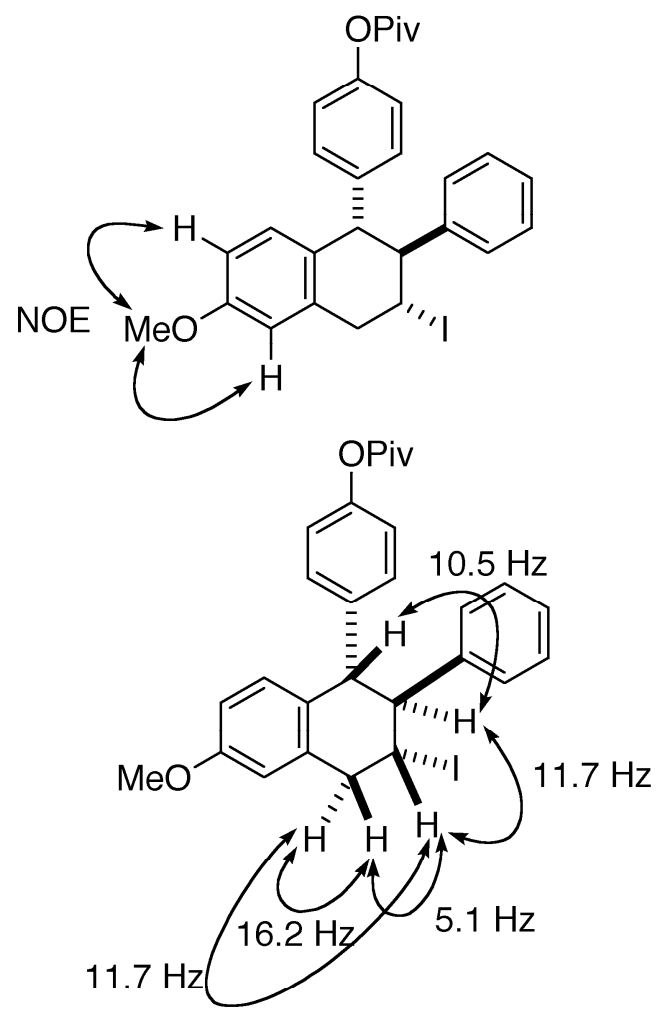

Compound 8

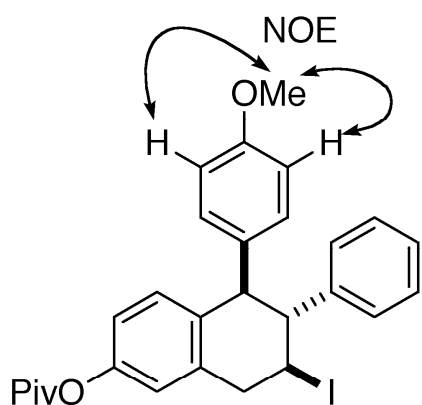

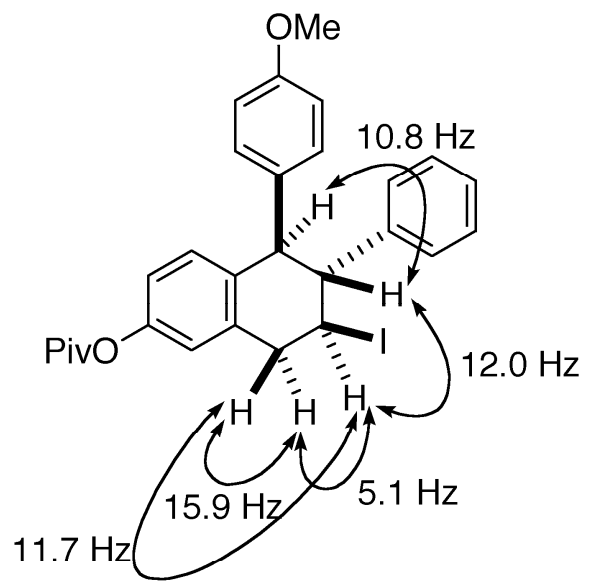

Compound 9

To assess the electronic effect of the aromatic rings in the iodonium cation-mediated cyclization to form the positional isomers $\mathbf{8}$ and $\mathbf{9}$, the three-component coupling product $\mathbf{1 0}$ having a strong electron withdrawing group at the para-position in one of aromatic rings was prepared and subjected to the iodine-induced cationic cyclization using $\mathrm{I}(\mathrm{py}){ }_{2} \mathrm{BF}_{4}$ (Scheme 4). 
Scheme 4. Iodine-induced cationic carbocyclization of the coupling product $\mathbf{1 0 .}$

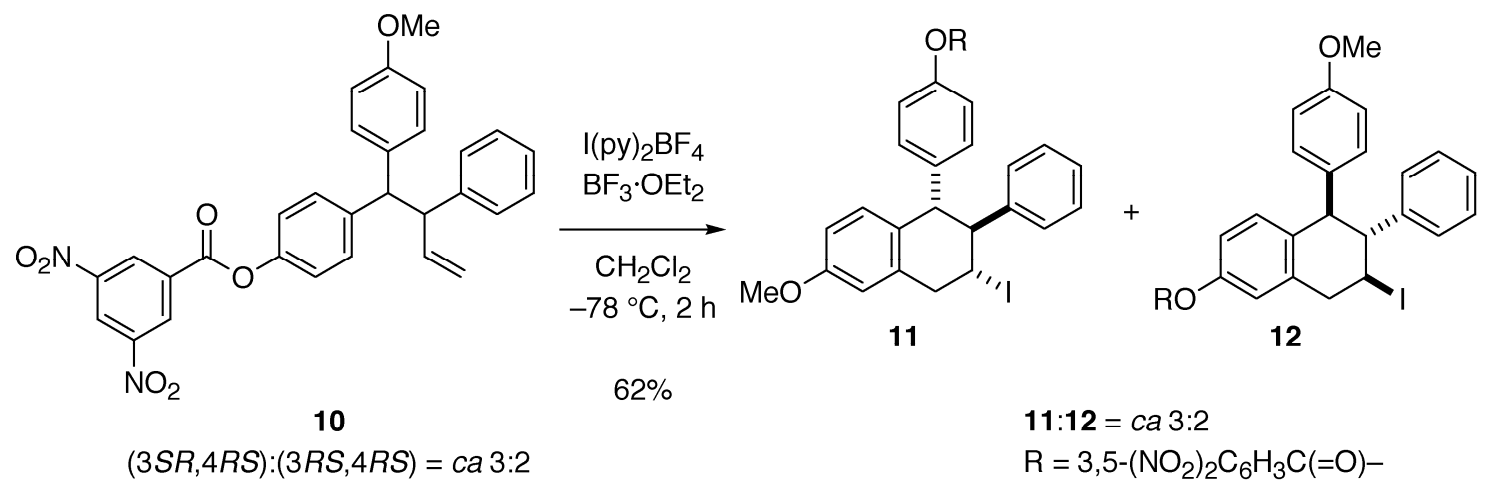

Interestingly, the carbocyclization smoothly proceeded to afford the cyclized compounds (11 and 12) in $62 \%$ yield $(\mathbf{1 1 : 1 2}=$ ca 3:2) with the same chemoselectivity, which was observed in the cyclization of $\mathbf{7}$ to produce 8 and $\mathbf{9}(\mathbf{8 : 9}=$ ca $3: 2)$. Therefore, it was proved that the selectivity of the cyclization of $\mathbf{7}$ to form the positional isomers $\mathbf{8}$ and $\mathbf{9}$ does not depend on the electronic effect of the substituents on the aromatic rings at the $\mathrm{C}-4$ position in 7 .

Based on the above experimental results, we concluded that the ratio of 8 and $\mathbf{9}$ generated from $\mathbf{7}$ by the carbocyclization was completely reflected in that composition of the two stereoisomers, anti(3SR,4RS)-7 and syn-(3RS,4RS)-7, included in the mixture of the starting material 7. The proposed pathways for the transformation of anti-(3SR,4RS)-7 into 8 and that of syn-(3RS,4RS)-7 into 9 were depicted in Scheme 5. The treatment of anti-(3SR,4RS)-7 with iodonium cation "I" " once affords intermediate anti-7-int by the approaching of the iodonium cation from the opposite site against the aromatic ring at the $\mathrm{C}-3$ position. Moreover, there exist two transition states ts-1 and ts-2 resulting 1,2-cis-2,3-trans-bicycle 8' and 1,2-trans-2,3-trans-bicycle 8, respectively, by the carbocyclization of anti-7-int. Apparently, the former transition state ts-1 has an unstable structure due to the steric repulsion between the two aromatic rings, so that another pathway to form the desired trans-transisomer 8 via ts- 2 would be preferable in this reaction.

On the other hand, syn-7-int would be generated from the iodonium cation with syn-(3RS,4RS)-7 by way of the similar complexation of these two components as above. There are also two transition states ts-3 and ts-4 which could turn into 1,2-trans-2,3-trans-bicycle 9 and 1,2-cis-2,3-trans-bicycle 9', respectively, by the carbocyclization of syn-7-int. The formation of an unstable transition state ts-4 should be effectively prohibited by the existence of the neighboring two aryl groups at the C-1 and C-2 positions with cis-configuration; therefore, the corresponding trans-trans-isomer 9 was exclusively obtained through the transition state ts-3 starting from syn-(3RS,4RS)-7, which was produced by the three-component coupling reaction as a minor stereoisomer. 
Scheme 5. Reaction pathway to give 1,2-trans-2,3-trans-bicycles 8 and 9 from anti$(3 S R, 4 R S)-7$ and syn-(3RS,4RS)-7, respectively.<smiles>C=C[C@H](c1ccccc1)c1ccc(Oc2ccc(OC)cc2)cc1</smiles>

anti-(3SR,4RS)-7

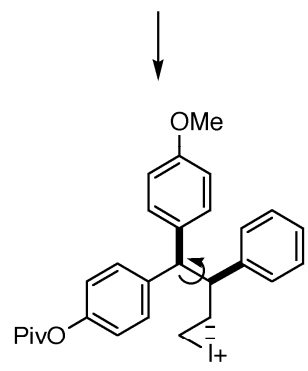

anti-7-int

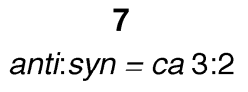

anti:syn = ca $3: 2$

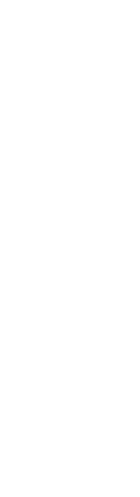

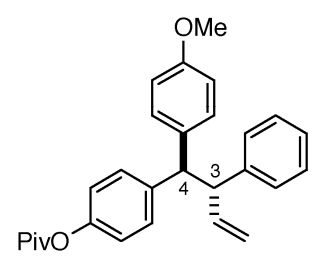

syn-(3RS,4RS)-7

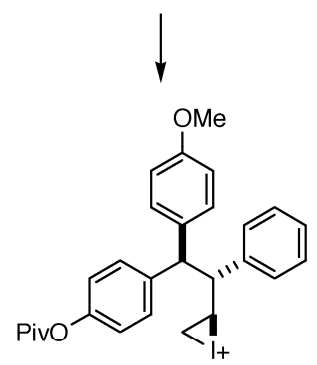

syn-7-int

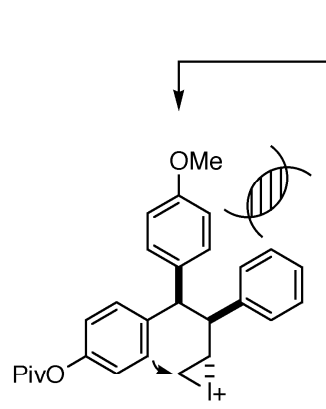

ts-1

市

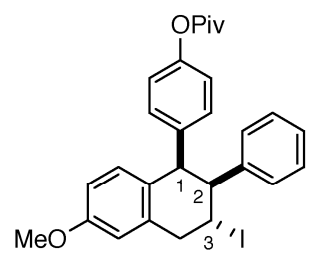

$\mathbf{8}^{\prime}$

1,2-cis-2,3-trans
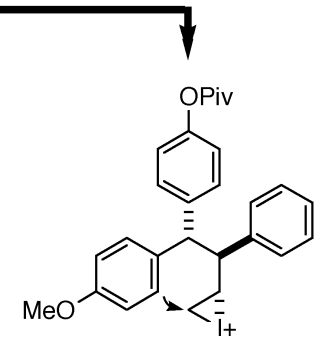

ts-2

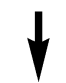

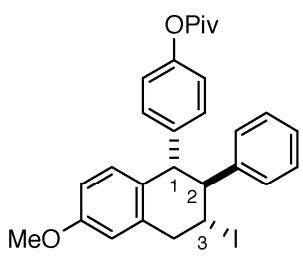

8

1,2-trans-2,3-trans

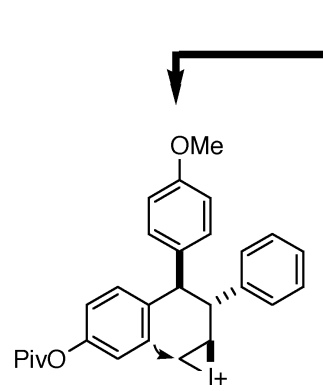

ts-3

$\downarrow$

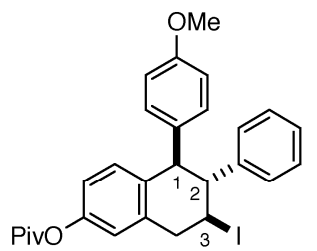

9

1,2-trans-2,3-trans

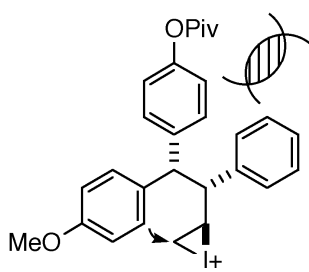

ts-4

文<smiles>COc1ccc([C@@H]2c3ccc(Oc4ccccc4)cc3C[C@H](I)[C@H]2c2ccccc2)cc1</smiles>

$9^{\prime}$

1,2-cis-2,3-trans

$8: 9=\operatorname{ca} 3: 2$

\subsection{Total Synthesis of Lasofoxifene (1), Nafoxidine (2), inv-Lasofoxifene (3), and inv-Nafoxidine (4)}

Next, the conversion of two positional isomers $\mathbf{8}$ and $\mathbf{9}$ into the common frameworks of lasofoxifene (1), nafoxidine (2), inv-lasofoxifene (3), and inv-nafoxidine (4) was attempted as shown in Schemes 6-8. The dehydroiodination of $\mathbf{8}$ and $\mathbf{9}$ by treatment with DBU was preliminarily carried out to give 75\% yield of the desired dihydronaphthalenes 13 and inv-13 in each case (Scheme 6). According to our previous study, the double-bond migration of $\mathbf{1 3}$ and inv-13 was then carried out 
using $t$ - $\mathrm{BuOK}$ in DMSO and the corresponding tetra-substituted olefins $\mathbf{1 4}$ and inv-14 having the free phenol moieties were successfully produced in good yields $(70 \%$ and $69 \%)$ via the simultaneous deprotection of the pivaloyl groups.

We further tried to explore the improved protocol to synthesize the universal precursor 14 of lasofoxifene (1) and nafoxidine (2) by the direct transformation of 8 into 14 using $t$-BuOK. During the early attempt to form $\mathbf{1 4}$ from $\mathbf{8}$ in the presence of $t$-BuOK in usually dried DMSO, uncharacterized over-aromatized compounds were unfortunately synthesized; however, successful conversion was finally attained using $t$-BuOK in degassed DMSO by freeze-and-thaw cycles as shown in Scheme 7. The total syntheses of nafoxidine (2) and lasofoxifene (1) were then accomplished via the successive introduction of the 2-pyrroridinoethyl moiety onto the hydroxyl group in the key intermediate $\mathbf{1 4}$ by the conventional method according to the report of Kapil et al. [43], followed by hydrogenation [33] and cleavage of the protective group in the methoxy substituent in 15 by $\mathrm{BBr}_{3}$ (Scheme 7).

Finally, the positional isomers of $\mathbf{1}$ and 2, inv-lasofoxifene (3) and inv-nafoxidine (4), were also prepared from iodine 9 in a similar manner (Scheme 8). It was revealed that the facile synthesis of invnafoxidine (4) was furnished in a $60 \%$ yield from iodine 9 via the successive olefin formation and the installation of the appropriate side-chain onto the phenol moiety of inv-14. After hydrogenating the double bond in $\mathbf{4}$ and the deprotection of methoxy group of inv-15, inv-lasofoxifene (3), one of our targeted molecules, was obtained in good yield via 2 steps from 4.

Scheme 6. Elimination of hydrogen iodide and double-bond migration reactions.

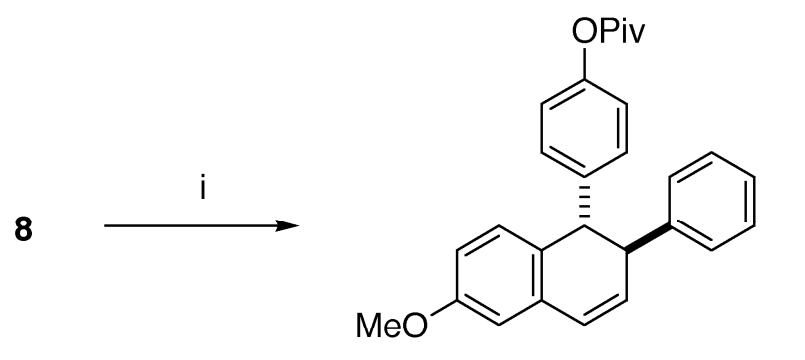

13

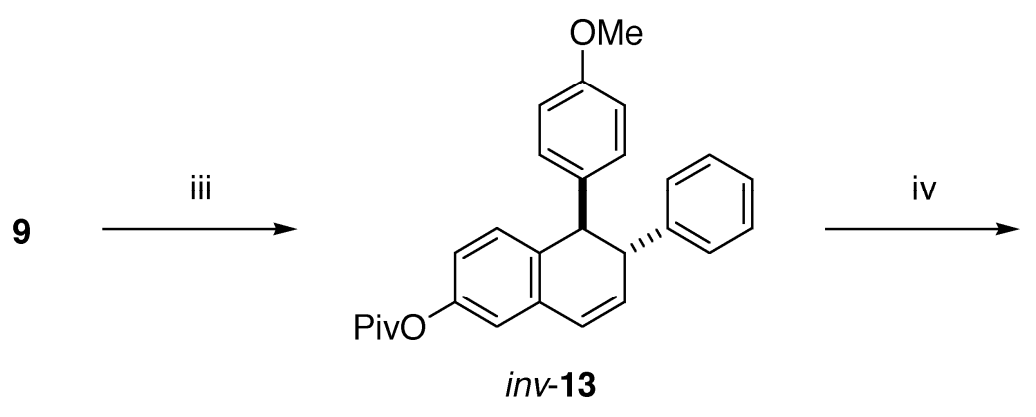<smiles>COc1ccc2c(c1)CCC(c1ccccc1)=C2c1ccc(O)cc1</smiles>

14<smiles>COc1ccc(C2=C(c3ccccc3)CCc3cc(O)ccc32)cc1</smiles>

inv-14

Reagents and conditions: (i) DBU (3.2 equiv.), toluene, $95{ }^{\circ} \mathrm{C}, 15 \mathrm{~min}, 75 \%$; (ii) $t$-BuOK (5.0 equiv.), DMSO, rt, $21 \mathrm{~h}, 70 \%$; (iii) DBU (3.2 equiv.), toluene, $95{ }^{\circ} \mathrm{C}, 15 \mathrm{~min}, 75 \%$; (iv) $t$-BuOK (7.8 equiv.), DMSO, $45^{\circ} \mathrm{C}, 3 \mathrm{~h}, 69 \%$. 
Scheme 7. Synthesis of lasofoxifene (1) and nafoxidine (2) via the direct conversion of iodide intermediate 8 into the common precursor 14.

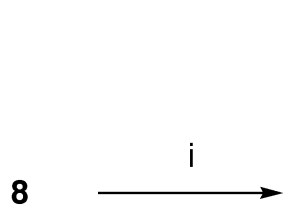<smiles>COc1ccc2c(c1)CCC(c1ccccc1)=C2c1ccc(O)cc1</smiles>

14

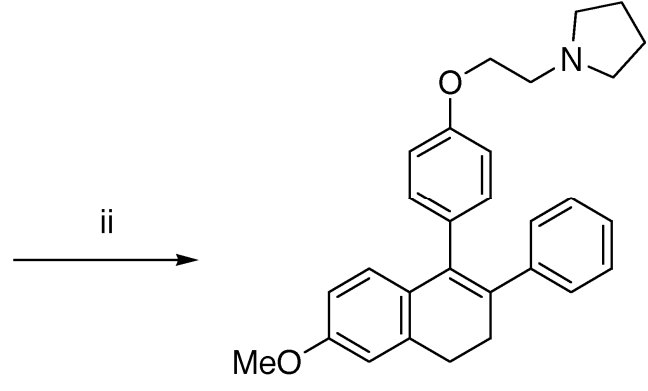

Nafoxidine (2)

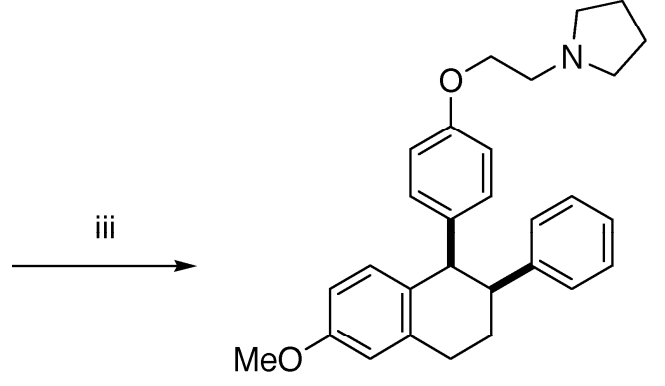

15

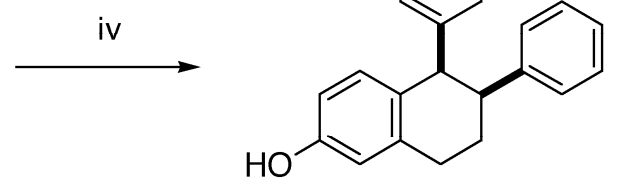

Lasofoxifene (1)

Reagents and conditions: (i) t-BuOK (4.0 equiv.), degassed DMSO, $90{ }^{\circ} \mathrm{C}, 1 \mathrm{~h}, 89 \%$; (ii) $\mathrm{Cl}\left(\mathrm{CH}_{2}\right)_{2} \mathrm{~N}\left(\mathrm{CH}_{2}\right)_{2} \cdot \mathrm{HCl}$ (2.0 equiv.), $\mathrm{NaH}$ (3.5 equiv.), DMF, $50{ }^{\circ} \mathrm{C}, 11 \mathrm{~h}, 82 \%$; (iii) $\mathrm{H}_{2}$ (2.5 atm), $\mathrm{Pd}(\mathrm{OH})_{2} / \mathrm{C}, \mathrm{EtOH}, 50{ }^{\circ} \mathrm{C}, 22 \mathrm{~h}, 70 \%$; (iv) $\mathrm{BBr}_{3}$ (5.0 equiv.), $\mathrm{CH}_{2} \mathrm{Cl}_{2},-23$ to $0{ }^{\circ} \mathrm{C}, 3 \mathrm{~h}, 76 \%$.

Scheme 8. Synthesis of inv-lasofoxifene (3) and inv-nafoxidine (4) from iodine 9.

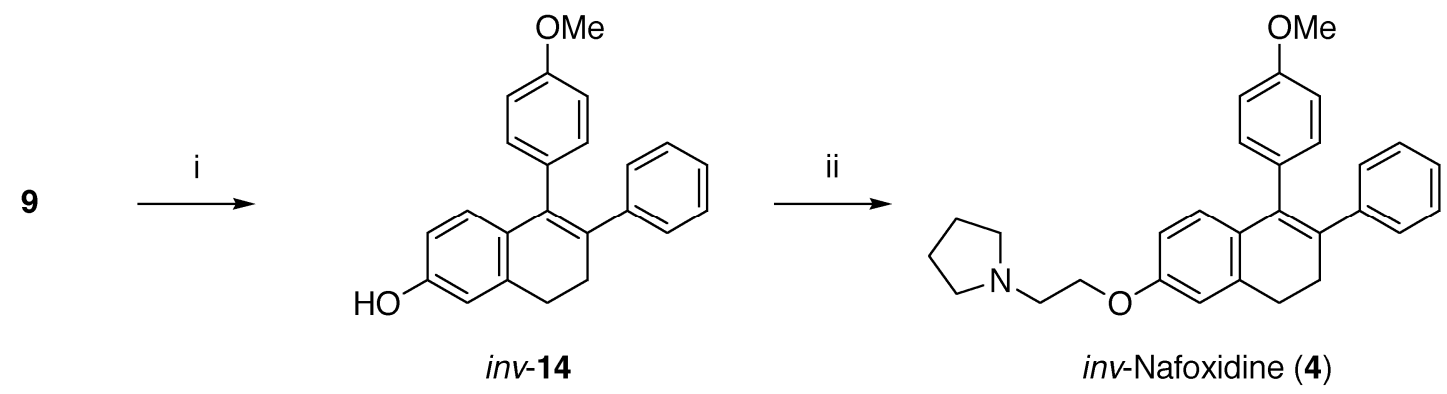

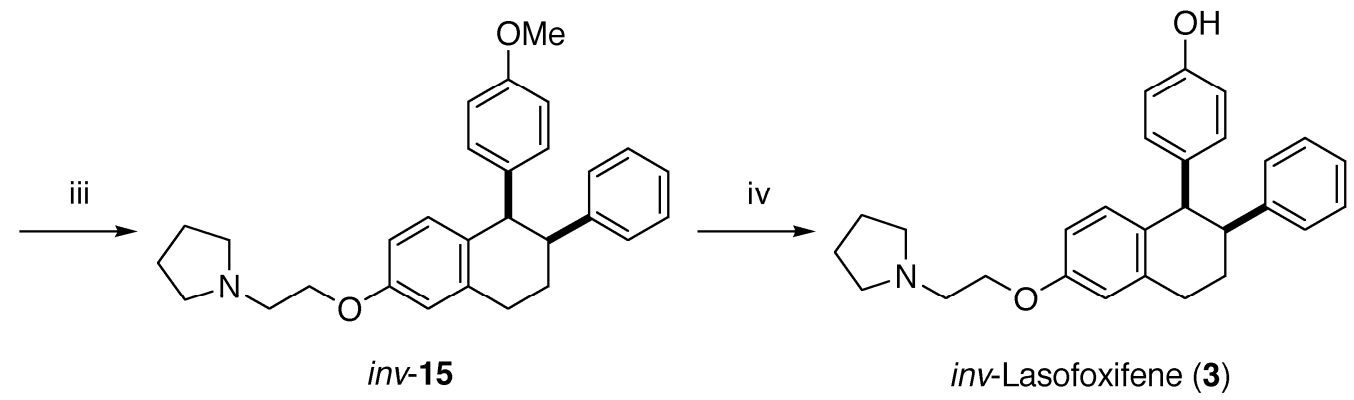

Reagents and conditions: (i) t-BuOK (4.0 equiv.), degassed DMSO, $90{ }^{\circ} \mathrm{C}, 1 \mathrm{~h}$; (ii) $\mathrm{Cl}\left(\mathrm{CH}_{2}\right)_{2} \mathrm{~N}\left(\mathrm{CH}_{2}\right)_{2} \cdot \mathrm{HCl}$ (1.8 equiv.), $\mathrm{NaH}$ (3.0 equiv.), DMF, $50{ }^{\circ} \mathrm{C}, 11 \mathrm{~h}, 60 \%$ (2 steps); (iii) $\mathrm{H} 2$ (2.5 atm), $\mathrm{Pd}(\mathrm{OH})_{2} / \mathrm{C}, \mathrm{EtOH}, 50{ }^{\circ} \mathrm{C}, 24 \mathrm{~h}, 79 \%$; (iv) $\mathrm{BBr}_{3}$ (5.0 equiv.), $\mathrm{CH}_{2} \mathrm{Cl}_{2},-78$ to $0{ }^{\circ} \mathrm{C}, 5 \mathrm{~h}$, $69 \%$. 


\section{Experimental}

\subsection{General}

All melting points are uncorrected. ${ }^{1} \mathrm{H}$ - and ${ }^{13} \mathrm{C}-\mathrm{NMR}$ spectra were recorded with chloroform (in chloroform-d) as internal standard. Column chromatography was performed on Silica gel 60 (Merck) or Wakogel B5F. Thin layer chromatography was performed on Wakogel B5F. All reactions were carried out under argon atmosphere in dried glassware, unless otherwise noted. Dichloromethane was distilled from diphosphorus pentoxide, then calcium hydride, and dried over MS 4A, toluene and anisole were distilled from sodium, and dried over MS 4A, and DMF and DMSO were distilled from calcium hydride, and dried over MS 4A. All reagents were purchased from Tokyo Kasei Kogyo Co., Ltd (TCI), Kanto Chemical Co., Inc. or Aldrich Chemical Co., Inc., and used without further purification unless otherwise noted. Cinnamyltrimethylsilane was purchased from Junsei Chemical Co., Ltd.

(3SR,4RS)/(3RS,4RS)-4-(4-Methoxyphenyl)-4-([4-pivaloyloxy]phenyl)-3-phenylbut-1-ene (7).

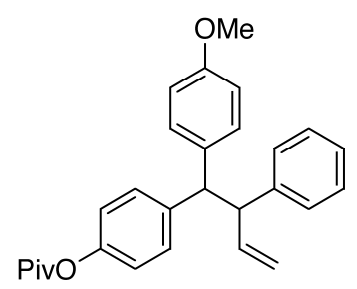

To a suspension of hafnium tetrachloride $(292.6 \mathrm{mg}, 0.9135 \mathrm{mmol})$ in anisole $(1 \mathrm{~mL})$ at room temperature was slowly added a mixture of cinnamyltrimethylsilane $(6,346.4 \mathrm{mg}, 1.820 \mathrm{mmol})$ and 4pivaloyloxybenzaldehyde $(5,188.4 \mathrm{mg}, 0.9134 \mathrm{mmol})$ in anisole $(2 \mathrm{~mL})$ with cooling in a water bath to maintain the reaction mixture at room temperature. The reaction mixture was stirred for $1 \mathrm{~h}$ at room temperature and then saturated aqueous sodium hydrogencarbonate was added. The mixture was extracted with diethyl ether and dried over sodium sulfate. After filtration of the mixture and evaporation of the solvent, the crude product was purified by silica gel column chromatography (ethyl acetate/hexane $=1 / 20$ to $1 / 9)$ to afford the coupling product $7(300.6 \mathrm{mg}, 79 \%,(o-) /(p-)=2: 98$, $(3 S R, 4 R S) /(3 R S, 4 R S)=c a 3: 2)$ as a colorless oil; IR (neat): 2974, 1749, 1610, 1511, 1252, 1203, 1167, 1120, 1032, 913, 818, 753, $700 \mathrm{~cm}-1 ;{ }^{1} \mathrm{H}-\mathrm{NMR}\left(\mathrm{CDCl}_{3}\right)$ : $\delta$ 7.35-7.27 (m, 1H, Ar), 7.26-6.94 (m, 9H, Ar), 6.86-6.73 (m, 2H, Ar), 6.64-6.57 (m, 1H, Ar), 6.00-5.80 (m, 1H, 2-H), 4.97-4.80 (m, 2H, 1-H), $4.26(\mathrm{~d}, J=11.4 \mathrm{~Hz}, 1 \mathrm{H}, 3-\mathrm{H}), 4.08(\mathrm{dd}, J=11.4,7.9 \mathrm{~Hz}, 1 \mathrm{H}, 4-\mathrm{H}), 3.75$ and 3.64 (s, 3H, OMe), 1.33 and $1.26\left(\mathrm{~s}, 9 \mathrm{H}, \mathrm{CMe}_{3}\right) ;{ }^{13} \mathrm{C}-\mathrm{NMR}\left(\mathrm{CDCl}_{3}\right): \delta 177.0$ and $176.8,158.0$ and $157.5,149.3$ and 148.9, 142.7 and 142.6, 141.1, 140.84 and 140.79, 135.3 and 135.1, 129.5 and 129.3, 129.1 and 129.0, 128.30 and 128.28, 128.25 and 128.20, 126.1 and 126.0, 121.2 and 120.9, 116.0 and 115.9, 113.8 and 113.5, 55.44 and 55.41, 55.1 and 55.0, 54.64 and 54.60, 39.0 and 38.9, 27.1 and 27.0; HR-MS: calcd for $\mathrm{C}_{28} \mathrm{H}_{30} \mathrm{O}_{3} \mathrm{Na}\left(\mathrm{M}+\mathrm{Na}^{+}\right)$437.2087, found 437.2101. 
(1SR,2SR,3RS)-3-Iodo-2-phenyl-1-([4-pivaloyloxy]phenyl)-(6-methoxy-1,2,3,4-tetrahydronaphthalene (8) and (1RS,2RS,3SR)-3-Iodo-2-phenyl-1-([4-methoxy] phenyl)-(6-pivaloyloxy-1,2,3,4-tetrahydronaphthalene) (9): To a suspension of $\mathrm{I}(\mathrm{py}){ }_{2} \mathrm{BF}_{4}(57.1 \mathrm{mg}, 0.154 \mathrm{mmol})$ in $\mathrm{CH}_{2} \mathrm{Cl}_{2}(3.4 \mathrm{~mL})$ at $-78{ }^{\circ} \mathrm{C}$ were slowly added the coupling product $7(56.0 \mathrm{mg}, 0.135 \mathrm{mmol})$ in $\mathrm{CH}_{2} \mathrm{Cl}_{2}(3.4 \mathrm{~mL})$ and $\mathrm{BF}_{3} \cdot \mathrm{OEt}_{2}$ $(150 \mu \mathrm{L}, 0.118 \mathrm{mmol})$. The reaction mixture was stirred for $2 \mathrm{~h}$ at the same temperature and then saturated aqueous ammonium chloride was added. The mixture was extracted with diethyl ether, and the organic layer was washed with brine, dried over sodium sulfate. After filtration of the mixture and evaporation of the solvent, the crude product was purified by thin layer chromatography (toluene) to afford iodine $8(29.9 \mathrm{mg}, 41 \%)$ as a pale vermilion solid and its positional isomer $9(20.0 \mathrm{mg}, 27 \%)$ as an amorphous product, respectively.

(1SR,2SR,3RS)-3-Iodo-2-phenyl-1-([4-pivaloyloxy]phenyl)-(6-methoxy-1,2,3,4-tetrahydronaphthalene) (8).

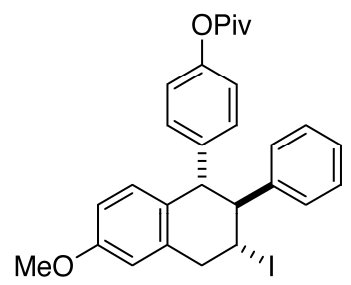

Mp. 66-68 ${ }^{\circ} \mathrm{C}$; IR (KBr): 2971, 1750, 1610, 1503, 1271, 1119, $1032 \mathrm{~cm}-1 ;{ }^{1} \mathrm{H}-\mathrm{NMR}\left(\mathrm{CDCl}_{3}\right)$ : 反 7.16-7.07 (m, 3H, Ar), 6.84-6.77 (m, 2H, Ar), 6.75-6.63 (m, 4H, Ar), 6.54 (br s, 3H, Ar), 4.68 (ddd, $J=11.7,11.7,5.1 \mathrm{~Hz}, 1 \mathrm{H}, 3-\mathrm{H}), 4.13(\mathrm{~d}, J=10.5 \mathrm{~Hz}, 1 \mathrm{H}, 1-\mathrm{H}), 3.76(\mathrm{dd}, J=16.2,11.7 \mathrm{~Hz}, 1 \mathrm{H}$, 4-H $\alpha$ ), 3.67 (s, 3H, OMe), 3.65 (dd, $J=16.2,5.1 \mathrm{~Hz}, 1 \mathrm{H}, 4-\mathrm{H} \beta$ ), 3.21 (dd, $J=11.7,10.5 \mathrm{~Hz}, 1 \mathrm{H}, 2-$ $\mathrm{H}), 1.23\left(\mathrm{~s}, 9 \mathrm{H}, \mathrm{CMe}_{3}\right) ;{ }^{13} \mathrm{C}-\mathrm{NMR}\left(\mathrm{CDCl}_{3}\right): \delta 177.0,157.9,149.4,144.4,142.0,137.3,131.3,130.8$, 129.8, 128.2, 127.6, 127.0, 121.0, 113.2, 111.5, 60.0, 55.3, 53.4, 45.1, 39.0, 32.7, 27.1; HR-MS: calcd for $\mathrm{C}_{28} \mathrm{H}_{29} \mathrm{O}_{3} \mathrm{INa}\left(\mathrm{M}+\mathrm{Na}^{+}\right) 563.1054$, found 563.1055.

(1RS,2RS,3SR)-3-Iodo-1-([4-methoxy]phenyl)-2-phenyl-(6-pivaloyloxy-1,2,3,4-tetrahydronaphthalene) (9).

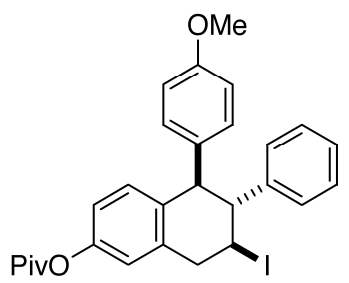

IR (neat): $2972,1750,1603,1571,1504,1266,1202,1119,1032 \mathrm{~cm}-1 ;{ }^{1} \mathrm{H}-\mathrm{NMR}\left(\mathrm{CDCl}^{3}\right): \delta 7.23-$ 7.16 (m, 3H, Ar), 6.92-6.86 (m, 2H, Ar), 6.83-6.79 (br s, 1H, Ar), 6.76-6.71 (m, 2H, Ar), 6.69-6.62 (m, 4H, Ar), 4.77 (ddd, $J=12.0,11.7,5.1 \mathrm{~Hz}, 1 \mathrm{H}, 3-\mathrm{H}), 4.19$ (d, $J=10.2 \mathrm{~Hz}, 1 \mathrm{H}, 1-\mathrm{H}), 3.87$ (dd, $J=15.9,11.7 \mathrm{~Hz}, 1 \mathrm{H}, 4-\mathrm{H} \alpha), 3.75(\mathrm{dd}, J=15.9,5.1 \mathrm{~Hz}, 1 \mathrm{H}, 4-\mathrm{H} \beta), 3.72(\mathrm{~s}, 3 \mathrm{H}, \mathrm{OMe}), 3.32$ (dd, $J=12.0,10.2 \mathrm{~Hz}, 1 \mathrm{H}, 2-\mathrm{H}), 1.35\left(\mathrm{~s}, 9 \mathrm{H}, \mathrm{CMe}_{3}\right) ;{ }^{13} \mathrm{C}-\mathrm{NMR}\left(\mathrm{CDCl}_{3}\right): \delta 177.2,158.0,149.2,144.5$, 137.3, 136.6, 136.3, 131.2, 129.9, 128.1, 127.6, 126.9, 119.9, 119.8, 113.4, 59.9, 55.1, 53.3, 44.8, 39.0, 32.2, 27.1; HR-MS: calcd for $\mathrm{C}_{28} \mathrm{H}_{29} \mathrm{O}_{3} \mathrm{INa}\left(\mathrm{M}+\mathrm{Na}^{+}\right)$563.1054, found 563.1080. 


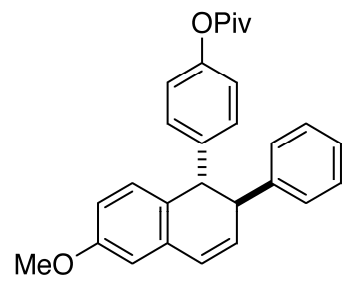

To a solution of iodine $8(39.4 \mathrm{mg}, 0.0729 \mathrm{mmol})$ in toluene $(1.5 \mathrm{~mL})$ at room temperature was added DBU $(35.0 \mu \mathrm{L}, 0.234 \mathrm{mmol})$. The reaction mixture was stirred for $15 \mathrm{~min}$ at $95{ }^{\circ} \mathrm{C}$ and then saturated aqueous ammonium chloride was added at $0{ }^{\circ} \mathrm{C}$. The mixture was extracted with diethyl ether, and the organic layer was washed with brine, dried over sodium sulfate. After filtration of the mixture and evaporation of the solvent, the crude product was purified by thin layer chromatography (benzene/hexane $=10: 1)$ to afford dihydronaphtalene $13(22.7 \mathrm{mg}, 75 \%)$ as a colorless oil; IR (neat): 2972, 1750, 1610, 1511, 1243, 1122, $1031 \mathrm{~cm}-1 ;{ }^{1} \mathrm{H}-\mathrm{NMR}\left(\mathrm{CDCl}_{3}\right): \delta 7.24-7.06(\mathrm{~m}, 7 \mathrm{H}, \mathrm{Ar}), 6.95-$ 6.59 (m, 6H, 4-H, Ar), 5.98 (dd, $J=9.6,4.2 \mathrm{~Hz}, 1 \mathrm{H}, 3-\mathrm{H}), 4.17$ (d, $J=7.5 \mathrm{~Hz}, 1 \mathrm{H}, 1-\mathrm{H}), 3.82$ (ddd, $J=$ 7.5, 4.2, $2.1 \mathrm{~Hz}, 1 \mathrm{H}, 2-\mathrm{H}), 3.80$ (s, 3H, OMe), 1.34 (s, 9H, $\left.\mathrm{CMe}_{3}\right) ;{ }^{13} \mathrm{C}-\mathrm{NMR}\left(\mathrm{CDCl}_{3}\right): \delta 177.1,158.6$, 149.4, 143.7, 142.0, 134.4, 130.9, 129.8, 129.3, 128.4, 128.2, 127.9, 127.8, 126.5, 121.2, 112.7, 111.9, 55.3, 51.2, 49.6, 39.0, 27.1; HR-MS: calcd for $\mathrm{C}_{28} \mathrm{H}_{28} \mathrm{O}_{3} \mathrm{Na}\left(\mathrm{M}+\mathrm{Na}^{+}\right) 435.1931$, found 435.1946 .

(1RS,2RS)-1-([4-Methoxy]phenyl)-2-phenyl-(6-pivaloyloxy-1,2-dihydronaphtalene) (inv-13).

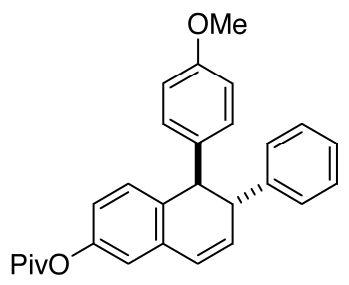

To a solution of iodine $9(28.1 \mathrm{mg}, 0.0520 \mathrm{mmol})$ in toluene $(1 \mathrm{~mL})$ at room temperature was added DBU $(25.0 \mu \mathrm{L}, 0.167 \mathrm{mmol})$. The reaction mixture was stirred for $15 \mathrm{~min}$ at $95{ }^{\circ} \mathrm{C}$ and then saturated aqueous ammonium chloride was added at $0{ }^{\circ} \mathrm{C}$. The mixture was extracted with diethyl ether, and the organic layer was washed with brine, dried over sodium sulfate. After filtration of the mixture and evaporation of the solvent, the crude product was purified by thin layer chromatography (benzene/hexane $=10: 1)$ to afford dihydronaphtalene inv-13 $(16.0 \mathrm{mg}, 75 \%)$ as a colorless oil; IR (neat): 3029, 2973, 2933, 1750, 1510, 1491, 1246, 1148, 1121, 1032, $703 \mathrm{~cm}^{-1} ;{ }^{1} \mathrm{H}-\mathrm{NMR}\left(\mathrm{CDCl}_{3}\right)$ : ס 7.24-6.97 (m, 7H, Ar), 6.89 (d, $J=2.1 \mathrm{~Hz}, 1 \mathrm{H}, \mathrm{Ar}), 6.83-6.72(\mathrm{~m}, 4 \mathrm{H}, \mathrm{Ar}), 6.62$ (dd, $J=9.6,1.8 \mathrm{~Hz}$, $1 \mathrm{H}, 4-\mathrm{H}), 6.01$ (dd, $J=9.6,4.2 \mathrm{~Hz}, 1 \mathrm{H}, 3-\mathrm{H}), 4.16$ (d, $J=7.8 \mathrm{~Hz}, 1 \mathrm{H}, 1-\mathrm{H}), 3.84$ (ddd, $J=7.8,4.2,1.8$ $\mathrm{Hz}, 1 \mathrm{H}, 2-\mathrm{H}), 3.76$ (s, 3H, OMe), 1.36 (s, 9H, $\left.\mathrm{CMe}_{3}\right) ;{ }^{13} \mathrm{C}-\mathrm{NMR}\left(\mathrm{CDCl}_{3}\right): \delta 177.2,158.1,149.9,143.7$, 136.2, 134.5, 133.9, 131.4, 129.7, 129.4, 128.4, 127.9, 127.2, 126.5, 120.2, 119.0, 113.7, 55.2, 51.1, 49.5, 39.1, 27.1; HR-MS: calcd for $\mathrm{C}_{28} \mathrm{H}_{28} \mathrm{O}_{3} \mathrm{Na}\left(\mathrm{M}+\mathrm{Na}^{+}\right)$435.1931, found 435.1940. 


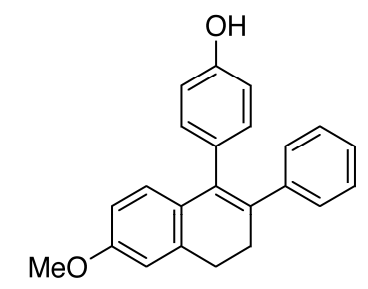

(Method A; Stepwise procedure from 13)

To a solution of potassium tert-butoxide $(40.3 \mathrm{mg}, 0.359 \mathrm{mmol})$ in DMSO $(0.6 \mathrm{~mL})$ at room temperature was added dihydronaphtalene $13(29.3 \mathrm{mg}, 0.071 \mathrm{mmol})$ in DMSO $(0.8 \mathrm{~mL})$. The reaction mixture was stirred for $21 \mathrm{~h}$ at room temperature and then saturated aqueous ammonium chloride was added at $0{ }^{\circ} \mathrm{C}$. The mixture was extracted with diethyl ether, and the organic layer was washed with brine, dried over sodium sulfate. After filtration of the mixture and evaporation of the solvent, the crude product was purified by thin layer chromatography (toluene/ethyl acetate $=10: 1$ ) to afford the common intermediate $14(16.0 \mathrm{mg}, 70 \%)$ as a pale yellow oil; ${ }^{1} \mathrm{H}-\mathrm{NMR}\left(\mathrm{CDCl}_{3}\right): \delta 7.19-6.99(\mathrm{~m}, 5 \mathrm{H}$, Ar), 6.94-6.88 (m, 2H, Ar), 6.82-6.66 (m, 4H, Ar), 6.60 (dd, J = 8.4, 3.0 Hz, 1H, Ar), 5.48 (br s, 1H, $\mathrm{OH}), 3.81$ (s, 3H, OMe), 2.99-2.87 (m, 2H, 4-H), 2.83-2.72 (m, 2H, 3-H). Above prepared 14 was instantly used in the following reaction as soon as possible.

(Method B; One-step procedure from 8)

To iodine 8 (74.4 mg, $0.138 \mathrm{mmol})$ at room temperature was added a solution of potassium tertbutoxide in degassed DMSO $(0.5 \mathrm{M}, 1.10 \mathrm{~mL}, 0.550 \mathrm{mmol})$. The reaction mixture was stirred for $1 \mathrm{~h}$ at $90{ }^{\circ} \mathrm{C}$ and then saturated aqueous ammonium chloride was added at $0{ }^{\circ} \mathrm{C}$. The mixture was extracted with diethyl ether/hexane $=1: 1$, and the organic layer was dried over sodium sulfate. After filtration of the mixture and evaporation of the solvent, the crude product was purified by silica gel column chromatography (hexane/ethyl acetate $=4: 1)$ to afford the common intermediate $14(41.1 \mathrm{mg}, 89 \%)$ as a pale yellow oil. Above prepared $\mathbf{1 4}$ was instantly used in the following reaction as soon as possible.

1-([4-Methoxy]phenyl)-2-phenyl-(6-hydroxy-3,4-dihydronaphtalene) (inv-14).

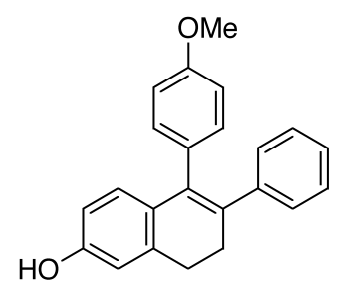

(Method A; Stepwise procedure from inv-13)

To a solution of potassium tert-butoxide $(31.7 \mathrm{mg}, 0.282 \mathrm{mmol})$ in DMSO $(0.32 \mathrm{~mL})$ at room temperature was added dihydronaphtalene inv-13 $(14.9 \mathrm{mg}, 0.0361 \mathrm{mmol})$ in DMSO $(0.40 \mathrm{~mL})$. The reaction mixture was stirred for $3 \mathrm{~h}$ at $45{ }^{\circ} \mathrm{C}$ and then saturated aqueous ammonium chloride was added at $0{ }^{\circ} \mathrm{C}$. The mixture was extracted with diethyl ether, and the organic layer was dried over sodium 
sulfate. After filtration of the mixture and evaporation of the solvent, the crude product was purified by thin layer chromatography (toluene/ethyl acetate $=10: 1)$ to afford the common intermediate inv-14 $(8.2$ $\mathrm{mg}, 69 \%)$ as a pale yellow oil; ${ }^{1} \mathrm{H}-\mathrm{NMR}\left(\mathrm{CDCl}_{3}\right): \delta 7.12-6.81(\mathrm{~m}, 7 \mathrm{H}, \mathrm{Ar}), 6.70-6.53(\mathrm{~m}, 4 \mathrm{H}, \mathrm{Ar})$, $6.40(\mathrm{dd}, J=8.4,2.4 \mathrm{~Hz}, 1 \mathrm{H}, \mathrm{Ar}), 5.10$ (br s, 1H, OH), 3.67 (s, 3H, OMe), 2.82-2.76 (m, 2H, 4-H), 2.71-2.63 (m, 2H, 3-H). Above prepared inv-14 was instantly used in the following reaction as soon as possible.

(Method B; One-step procedure from 9)

To iodine 9 (48.3 mg, $0.0894 \mathrm{mmol})$ at room temperature was added a solution of potassium tertbutoxide in degassed DMSO $(0.5 \mathrm{M}, 0.715 \mathrm{~mL}, 0.358 \mathrm{mmol})$. The reaction mixture was stirred for $1 \mathrm{~h}$ at $90{ }^{\circ} \mathrm{C}$ and then saturated aqueous ammonium chloride was added at $0{ }^{\circ} \mathrm{C}$. The mixture was extracted with diethyl ether/hexane $=1: 1$, and the organic layer was washed with brine, dried over sodium sulfate. After filtration of the mixture and evaporation of the solvent, the crude intermediate inv-14 was used for the next reaction to provide $\mathbf{4}$ without further purification.

Nafoxidine (2).

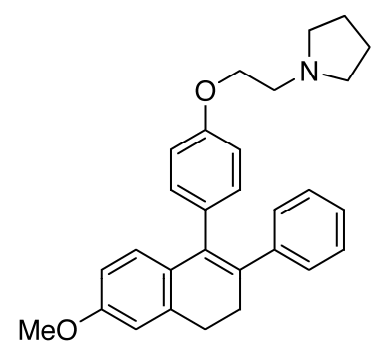

To a solution of alcohol $14(31.7 \mathrm{mg}, 0.0965 \mathrm{mmol})$ in DMF (1 mL) at room temperature was gradually added sodium hydride $(60 \%, 13.4 \mathrm{mg}, 0.335 \mathrm{mmol})$. After the reaction mixture had been stirred for $20 \mathrm{~min}$ at the same temperature, 1-(2-chloroethyl)pyrrolidine hydrochloride (33.4 $\mathrm{mg}, 0.196$ mmol) was added to the reaction mixture. The reaction mixture was stirred for $11 \mathrm{~h}$ at $50{ }^{\circ} \mathrm{C}$ and then saturated aqueous sodium hydrogencarbonate was added at $0{ }^{\circ} \mathrm{C}$. The mixture was extracted with ethyl acetate, and dried over sodium sulfate. After filtration of the mixture and evaporation of the solvent, the crude product was purified by thin layer chromatography (hexane/ethyl acetate/35\% $\mathrm{NH}_{3}=7: 3: 1$ ) to afford nafoxidine (2) $(33.5 \mathrm{mg}, 82 \%)$ as a pale yellow oil; IR (neat): 3031, 2936, 1669, 1606, 1568, 1508, 1241, 1174, $1037 \mathrm{~cm}^{-1} ;{ }^{1} \mathrm{H}-\mathrm{NMR}\left(\mathrm{CDCl}_{3}\right): \delta$ 7.14-6.92 (m, 7H, Ar), 6.80-6.69 (m, 4H, Ar), 6.59 (dd, $J=9.0,2.5 \mathrm{~Hz}, 1 \mathrm{H}, \mathrm{Ar}), 4.18\left(\mathrm{t}, J=6.0 \mathrm{~Hz}, 2 \mathrm{H}, \mathrm{OCH}_{2}\right), 3.80$ (s, 3H, OMe), 3.18-3.01 (m, 2H, $\mathrm{NCH}_{2}$ ), 2.94-2.72 (m, 8H, 3-H, 4-H, pyrrolidinyl 2-H), 1.94-1.88 (m, 4H, pyrrolidinyl 3-H); ${ }^{13} \mathrm{C}-\mathrm{NMR}\left(\mathrm{CDCl}_{3}\right): \delta 158.4,157.0,143.2,137.7,134.6,134.3,132.2,130.4,128.2,127.60,127.55$, 127.4, 125.6, 114.0, 113.2, 110.8, 65.9, 55.3, 54.8, 54.6, 30.7, 29.0, 23.4; HR-MS: calcd for $\mathrm{C}_{29} \mathrm{H}_{32} \mathrm{O}_{2} \mathrm{~N}\left(\mathrm{M}+\mathrm{H}^{+}\right)$426.2428, found 426.2430. 
inv-Nafoxidine (4).

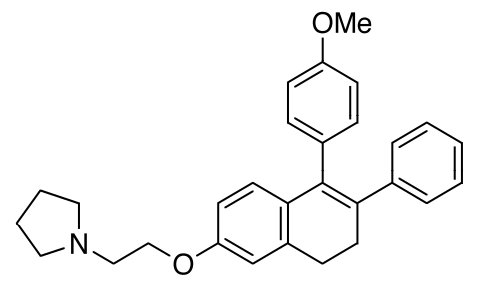

To a solution of the crude inv-14 derived from iodine 9 in DMF $(1 \mathrm{~mL})$ at room temperature was gradually added sodium hydride $(60 \%, 10.7 \mathrm{mg}, 0.268 \mathrm{mmol})$. After the reaction mixture had been stirred for $20 \mathrm{~min}$ at the same temperature, 1-(2-chloroethyl)pyrrolidine hydrochloride $(27.4 \mathrm{mg}$, $0.161 \mathrm{mmol}$ ) was added to the reaction mixture. The reaction mixture was stirred at $50{ }^{\circ} \mathrm{C}$ for $11 \mathrm{~h}$ and then saturated aqueous sodium hydrogen carbonate was added at $0{ }^{\circ} \mathrm{C}$. The mixture was extracted with ethyl acetate, and dried over sodium sulfate. After filtration of the mixture and evaporation of the solvent, the crude product was purified by thin layer chromatography $\left(\mathrm{CHCl}_{3} / \mathrm{MeOH}=9: 1\right)$ to afford inv-nafoxidine (4) $(22.7 \mathrm{mg}, 60 \%$ from 9) as a pale yellow oil; IR (neat): 2963, 2784, 1606, 1511, 1243, 1036, 831, 758, $700 \mathrm{~cm}^{-1} ;{ }^{1} \mathrm{H}-\mathrm{NMR}\left(\mathrm{CDCl}_{3}\right): \delta$ 7.17-6.93 (m, 7H, Ar), 6.82-6.69 (m, 4H, Ar), $6.61(\mathrm{dd}, J=8.4,2.7 \mathrm{~Hz}, 1 \mathrm{H}, \mathrm{Ar}), 4.11\left(\mathrm{t}, J=6.0 \mathrm{~Hz}, 2 \mathrm{H}, \mathrm{OCH}_{2}\right), 3.78(\mathrm{~s}, 3 \mathrm{H}, \mathrm{OMe}), 3.00-2.85(\mathrm{~m}$, $\left.4 \mathrm{H}, 4-\mathrm{H}, \mathrm{NCH}_{2}\right), 2.82-2.73(\mathrm{~m}, 2 \mathrm{H}, 3-\mathrm{H}), 2.72-2.56(\mathrm{~m}, 4 \mathrm{H}$, pyrrolidinyl 2-H), 1.87-1.75 (m, 4H, pyrrolidinyl 3-H); ${ }^{13} \mathrm{C}-\mathrm{NMR}\left(\mathrm{CDCl}_{3}\right): \delta 158.0,157.6,143.3,137.6,134.7,134.2,132.1,132.0,130.5$, 128.2 , 127.5, 127.4, 125.6, 113.8, 113.3, 111.4, 67.0, 55.08, 55.06, 54.7, 30.7, 28.9, 23.4; HR-MS: calcd for $\mathrm{C}_{29} \mathrm{H}_{32} \mathrm{O}_{2} \mathrm{~N}\left(\mathrm{M}+\mathrm{H}^{+}\right) 426.2428$, found 426.2438.

(1RS,2SR)-1-(4-[2-Pyrrolidinoethoxy]phenyl)-2-phenyl-(6-methoxy-1,2,3,4-tetrahydronaphtalene) (15).

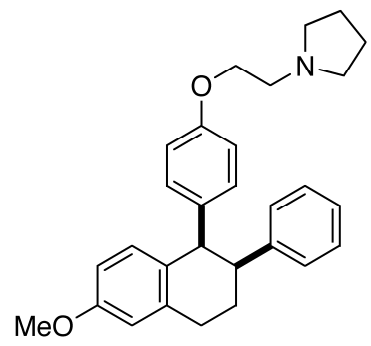

A $10 \mathrm{~mL}$ autoclave was charged with nafoxidine $(2,36.0 \mathrm{mg}, 0.0846 \mathrm{mmol}), 20 \% \mathrm{Pd}(\mathrm{OH})_{2} / \mathrm{C}(36.0$ $\mathrm{mg}, 0.0513 \mathrm{mmol})$, and EtOH $(3.0 \mathrm{~mL})$. The vessel was sealed and then the whole mixture was stirred for $22 \mathrm{~h}$ at $50{ }^{\circ} \mathrm{C}$ under hydrogen atmosphere (2.5 atm). After cooling to room temperature, the reactant was filtered through a short pad of Celite with EtOAc at room temperature under ambient atmosphere. The filtrate was concentrated and purified by silica gel chromatography (hexane/ethyl acetate/35\% $\left.\mathrm{NH}_{3}=7: 3: 1\right)$ to afford $15(25.2 \mathrm{mg}, 70 \%)$ as a colorless oil; IR (neat): 2932, 1608, 1506, 1460, 1240, 1178, 1155, 1038, $823 \mathrm{~cm}^{-1} ;{ }^{1} \mathrm{H}-\mathrm{NMR}\left(\mathrm{CDCl}_{3}\right): \delta 7.21-7.12(\mathrm{~m}, 3 \mathrm{H}, \mathrm{Ar}), 6.90-6.64(\mathrm{~m}$, 5H, Ar), 6.59-6.52 (m, 2H, Ar), 6.36-6.27 (m, 2H, Ar), 4.24 (d, J=5.1 Hz, 1H, 1-H), 4.00 (t, J=6.0 $\mathrm{Hz}, 1 \mathrm{H}, \mathrm{OCH}_{2}$ ), 3.82 (s, 3H, OMe), 3.36 (ddd, $\left.J=12.9,5.1,2.1 \mathrm{~Hz}, 1 \mathrm{H}, 2-\mathrm{H}\right), 3.15-3.06$ (m, 2H, 4-H), $2.85\left(\mathrm{t}, J=6.0 \mathrm{~Hz}, 2 \mathrm{H}, \mathrm{NCH}_{2}\right), 2.70-2.56(\mathrm{~m}, 4 \mathrm{H}$, pyrrolidinyl 2-H), 2.26-2.11 (m, 1H, 3-H), 1.89$1.76\left(\mathrm{~m}, 5 \mathrm{H}, 3-\mathrm{H}\right.$, pyrrolidinyl 3-H); ${ }^{13} \mathrm{C}-\mathrm{NMR}\left(\mathrm{CDCl}_{3}\right): \delta 157.8,156.8,144.3,137.7,134.7,132.2$, 
$131.5,131.3,128.1,127.7,125.9,112.94,112.91,112.5,66.5,55.2,55.0,54.6,50.2,45.4,30.1,23.4$, 21.9; HR-MS: calcd for $\mathrm{C}_{29} \mathrm{H}_{34} \mathrm{O}_{2} \mathrm{~N}\left(\mathrm{M}+\mathrm{H}^{+}\right) 428.2584$, found 428.2586 .

(1RS,2SR)-1-(4-[Methoxy]phenyl)-2-phenyl-(6-[2-pyrrolidinoethoxy]-1,2,3,4-tetrahydronaphtalene) (inv-15).

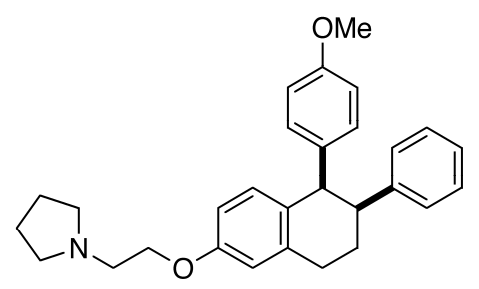

A $10 \mathrm{~mL}$ autoclave was charged with inv-nafoxidine $(4,14.9 \mathrm{mg}, 0.0350 \mathrm{mmol}), 20 \% \mathrm{Pd}(\mathrm{OH})_{2} / \mathrm{C}$ (15.0 $\mathrm{mg}, 0.0214 \mathrm{mmol})$, and $\mathrm{EtOH}(1.5 \mathrm{~mL})$. The vessel was sealed and then the whole mixture was stirred for $24 \mathrm{~h}$ at $50{ }^{\circ} \mathrm{C}$ under hydrogen atmosphere (2.5 atm). After cooling to room temperature, the reactant was filtered through a short pad of Celite with EtOAc at room temperature under ambient atmosphere. The filtrate was concentrated and purified by silica gel chromatography (hexane/ethyl acetate/35\% $\left.\mathrm{NH}_{3}=7: 3: 1\right)$ to afford inv-15 (11.8 $\left.\mathrm{mg}, 79 \%\right)$ as a colorless oil; IR (neat): 2931, 1608, 1505, 1459, 1242, 1037, 823, 755, $700 \mathrm{~cm}^{-1} ;{ }^{1} \mathrm{H}-\mathrm{NMR}\left(\mathrm{CDCl}_{3}\right): \delta 7.20-7.13(\mathrm{~m}, 3 \mathrm{H}, \mathrm{Ar}), 6.86(\mathrm{~d}$, $J=8.0 \mathrm{~Hz}, 1 \mathrm{H}, \mathrm{Ar}), 6.83-6.77$ (m, 3H, Ar), 6.70 (dd, $J=8.0,2.5 \mathrm{~Hz}, 1 \mathrm{H}, \mathrm{Ar}), 6.57-6.52$ (m, 2H, Ar), 6.36-6.29 (m, 2H, Ar), 4.24 (d, J=5.0 Hz, 1H, 1-H), 4.16-4.08 (m, 2H, OCH $), 3.70$ (s, 3H, OMe), 3.36 (ddd, $J=11.3,5.0,2.0 \mathrm{~Hz}, 1 \mathrm{H}, 2-\mathrm{H}), 3.10-3.01(\mathrm{~m}, 2 \mathrm{H}, 4-\mathrm{H}), 2.91\left(\mathrm{t}, J=6.0 \mathrm{~Hz}, 2 \mathrm{H}, \mathrm{NCH}_{2}\right.$ ), 2.70-2.61 (m, 4H, pyrrolidinyl 2-H), 2.26-2.11 (m, 1H, 3-H), 1.87-1.76 (m, 5H, 3-H, pyrrolidinyl 3$\mathrm{H}) ;{ }^{13} \mathrm{C}-\mathrm{NMR}\left(\mathrm{CDCl}_{3}\right): \delta 157.5,157.1,144.3,137.7,134.6,132.3,131.4,131.3,128.1,127.7,125.9$, 113.7, 113.1, 112.2, 66.9, 55.1, 55.0, 54.7, 50.1, 45.4, 30.1, 23.5, 21.9; HR-MS: calcd for $\mathrm{C}_{23} \mathrm{H}_{21} \mathrm{O}_{2} \mathrm{Na}$ $\left[\mathrm{M}-\left(\mathrm{C}_{4} \mathrm{H}_{8} \mathrm{~N}+\mathrm{CH}_{2}=\mathrm{CH}_{2}\right)+\mathrm{Na}^{+}\right] 352.1434$, found 352.1427 .

\section{Lasofoxifene (1).}

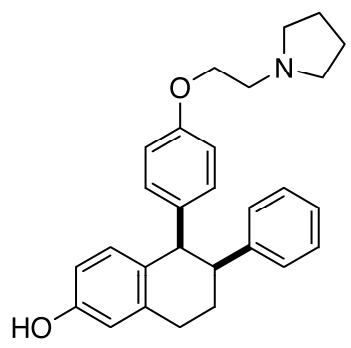

To a solution of methyl ether $15(10.1 \mathrm{mg}, 0.0236 \mathrm{mmol})$ in $\mathrm{CH}_{2} \mathrm{Cl}_{2}(0.6 \mathrm{~mL})$ at $-78{ }^{\circ} \mathrm{C}$ was slowly added $\mathrm{BBr}_{3}$ in $\mathrm{CH}_{2} \mathrm{Cl}_{2}(1.0 \mathrm{M}, 0.120 \mathrm{~mL}, 0.120 \mathrm{mmol})$. The reaction mixture was stirred for $1 \mathrm{~h}$ at $-23{ }^{\circ} \mathrm{C}$ and $2 \mathrm{~h}$ at $0{ }^{\circ} \mathrm{C}$ and then saturated aqueous sodium hydrogencarbonate was added at the same temperature. The mixture was extracted with ethyl acetate, and the organic layer was washed with brine, dried over sodium sulfate. After filtration of the mixture and evaporation of the solvent, the crude product was purified by thin layer chromatography (hexane/ethyl acetate/35\% $\mathrm{NH}_{3}=3: 6: 1$ ) to afford lasofoxifene (1, $7.4 \mathrm{mg}, 76 \%$ ) as a colorless oil; IR (neat): 3471, 2928, 2873, 1668, 1506, 1455, 1177, 1035, 823, $757 \mathrm{~cm}^{-1} ;{ }^{1} \mathrm{H}-\mathrm{NMR}\left(\mathrm{CDCl}_{3}\right): \delta 7.11-7.00(\mathrm{~m}, 3 \mathrm{H}, \mathrm{Ar}), 6.75-6.63(\mathrm{~m}, 3 \mathrm{H}, \mathrm{Ar}), 6.53$ 
$(\mathrm{d}, J=2.4 \mathrm{~Hz}, 1 \mathrm{H}, \mathrm{Ar}), 6.46(\mathrm{dd}, J=8.1,2.4 \mathrm{~Hz}, 1 \mathrm{H}, \mathrm{Ar}), 6.27(\mathrm{~d}, J=8.7 \mathrm{~Hz}, 2 \mathrm{H}, \mathrm{Ar}), 6.16(\mathrm{~d}, J=8.7$ $\mathrm{Hz}, 2 \mathrm{H}, \mathrm{Ar}$ ), 5.20 (br s, 1H, OH), 4.10 (d, J = 4.8 Hz, 1H, 1-H), 3.99-3.83 (m, 2H, OCH $), 3.24$ (ddd, $J=11.4,4.8,2.0 \mathrm{~Hz}, 1 \mathrm{H}, 2-\mathrm{H}), 3.00-2.60$ (m, 8H, 4-H, $\mathrm{NCH}_{2}$, pyrrolidinyl 2-H), 2.07-1.95 (m, 1H, 3$\mathrm{H}), 1.87-1.76\left(\mathrm{~m}, 5 \mathrm{H}, 3-\mathrm{H}\right.$, pyrrolidinyl 3-H); ${ }^{13} \mathrm{C}-\mathrm{NMR}\left(\mathrm{CDCl}_{3}\right): \delta 156.6,155.0,144.5,137.6,134.9$, $131.5,131.2$, 128.3, 128.2, 127.7, 125.9, 114.9, 114.0, 112.7, 65.6, 55.1, 54.4, 50.2, 45.4, 29.9, 23.2, 21.9; HR-MS: calcd for $\mathrm{C}_{28} \mathrm{H}_{32} \mathrm{O}_{2} \mathrm{~N}\left(\mathrm{M}+\mathrm{H}^{+}\right)$414.2428, found 414.2436.

inv-Lasofoxifene (3).

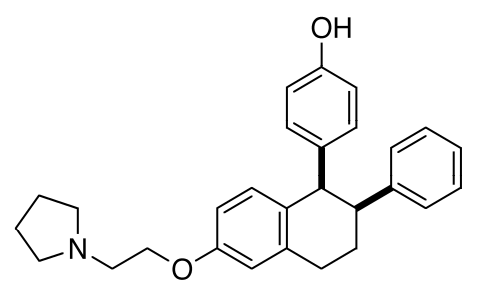

To a solution of methyl ether inv-15 $(11.8 \mathrm{mg}, 0.0276 \mathrm{mmol})$ in $\mathrm{CH}_{2} \mathrm{Cl}_{2}(0.7 \mathrm{~mL})$ at $-78{ }^{\circ} \mathrm{C}$ was slowly added $\mathrm{BBr}_{3}$ in $\mathrm{CH}_{2} \mathrm{Cl}_{2}(1.0 \mathrm{M}, 0.140 \mathrm{~mL}, 0.140 \mathrm{mmol})$. The reaction mixture was stirred for 1 $\mathrm{h}$ at $-78{ }^{\circ} \mathrm{C}$ and $4 \mathrm{~h}$ at $0{ }^{\circ} \mathrm{C}$ and then saturated aqueous sodium hydrogencarbonate was added at the same temperature. The mixture was extracted with ethyl acetate, and the organic layer was washed with brine, dried over sodium sulfate. After filtration of the mixture and evaporation of the solvent, the crude product was purified by thin layer chromatography (hexane/ethyl acetate/35\% $\mathrm{NH}_{3}=3: 6: 1$ ) to afford inv-lasofoxifene $(3,7.9 \mathrm{mg}, 69 \%)$ as a colorless oil; IR (neat): 3362, 2923, 1776, 1713, 1663, 1609, 1241, 1119, 1051, 991, $756 \mathrm{~cm}^{-1}$; ${ }^{1} \mathrm{H}-\mathrm{NMR}\left(\mathrm{CDCl}_{3}\right): \delta$ 7.20-7.11 (m, 3H, Ar), 6.85-6.77 (m, $3 \mathrm{H}, \mathrm{Ar}), 6.73(\mathrm{~d}, J=2.5 \mathrm{~Hz}, 1 \mathrm{H} \mathrm{Ar}), 6.60-6.55$ (m, 1H, Ar), 6.47-6.43 (m, 2H, Ar), 6.26-6.23 (m, 2H, Ar), 5.42 (br s, 1H, OH), 4.21 (d, J=5.0 Hz, 1H, 1-H), 4.16-4.06 (m, 2H, OCH $), 3.37-3.30(\mathrm{~m}, 1 \mathrm{H}$, 2-H), 3.09-2.90 (m, 4H, 4-H, $\left.\mathrm{NCH}_{2}\right), 2.61-2.54$ (m, 4H, pyrrolidinyl 2-H), 2.22-2.12 (m, 2H, 3-H), 1.89-1.77 (m, 4H, pyrrolidinyl 3-H); ${ }^{13} \mathrm{C}-\mathrm{NMR}\left(\mathrm{CDCl}_{3}\right): \delta 157.0,154.0,144.4,137.6,134.3,132.4$, 131.5, 131.4, 128.2, 127.7, 125.9, 114.0, 113.6, 113.1, 66.5, 55.1, 54.6, 50.2, 45.4, 30.1, 23.4, 21.9; HR-MS: calcd for $\mathrm{C}_{28} \mathrm{H}_{32} \mathrm{O}_{2} \mathrm{~N}\left(\mathrm{M}+\mathrm{H}^{+}\right)$414.2428, found 414.2432.

\section{Conclusions}

Thus, we developed a new method to produce lasofoxifene (1), nafoxidine (2) and their positional isomers inv-lasofoxifene (3) and inv-nafoxidine (4) using the three-component coupling reaction among 4-pivaloyloxybenzaldehyde (5), cinnamyltrimethylsilane (6), and anisole in the presence of $\mathrm{HfCl}_{4}$. The intermediate 3,4,4-triaryl-1-butene 7 was effectively transformed into 2 and 4, which were precursors of $\mathbf{1}$ and 3, respectively, via the successive three-step transformations; namely, electrophilic carbocyclization, sequential double-bond formation/migration, and side-chain installation. This synthetic strategy seems to serve as a novel and practical pathway to prepare not only the nafoxidine and lasofoxifene derivatives, but also new entries as SERM-type drugs including estrogen-dependent breast cancer, leukemia, and osteoporosis agents. 


\section{Supplementary Materials}

Spectroscopic data of synthetic intermediates and products is available free of charge at http://www.mdpi.com/1420-3049/15/10/6673/s1.

\section{Acknowledgements}

This work was partially supported by the Science Research Promotion Fund from the Promotion and Mutual Aid Corporation for Private Schools of Japan.

\section{References and Notes}

1. Ugi, I. Recent progress in the chemistry of multicomponent reactions. Pure Appl. Chem. 2001, 73, $187-191$.

2. Hulme, C. In Muticomponent Reactions; Zhu, J., Bienayme, H., Eds.; Wiley-VCH: Weinheim, 2005; pp. 311-341.

3. Eckert, H. From multi-component-reactions (MCRs) towards multi-function-component-reactions (MFCRs). Heterocycles 2007, 73, 149-158.

4. Ugi, I. Isonitrile Chemistry; Academic Press: New York, NY, USA/London, UK, 1971.

5. Doemling A.; Ugi, I. Multicomponent reactions with isocyanides. Angew. Chem. Int. Ed. 2000, 39, 3168-3210.

6. Wang, Z.; Zhou, L.; El-Boubbou, K.; Ye, X.; Huang, X. Multi-component one-pot synthesis of the tumor-associated carbohydrate antigen Globo-H based on preactivation of thioglycosyl donors. J. Org. Chem. 2007, 72, 6409-6420.

7. Hashihayata, T.; Ikegai, K.; Takeuchi, K.; Jona H.; Mukaiyama, T. Convergent total syntheses of oligosaccharides by one-pot sequential stereoselective glycosylations. Bull. Chem. Soc. Jpn. 2003, $76,1829-1848$.

8. D’Souza D.M.; Müller, T.J.J. Multi-component syntheses of heterocycles by transition-metal catalysis. Chem. Soc. Rev. 2007, 36, 1095-1108.

9. Perreault S.; Rovis, T. Multi-component cycloaddition approaches in the catalytic asymmetric synthesis of alkaloid targets. Chem. Soc. Rev. 2009, 38, 3149-3159.

10. Shiina, I.; Suzuki, M.; Yokoyama, K. A convenient method for the synthesis of 4,4-diarylbut-1enes via the successive allylation of aromatic aldehydes and the Friedel-Crafts alkylation reaction of aromatic nucleophiles with the intermediary benzyl silyl ethers using $\mathrm{HfCl}_{4}$ or $\mathrm{Cl}_{2} \mathrm{Si}(\mathrm{OTf})_{2}$. Tetrahedron Lett. 2002, 43, 6395-6398.

11. Shiina, I.; Suzuki, M. The catalytic Friedel-Crafts alkylation reaction of aromatic compounds with benzyl or allyl silyl ethers using $\mathrm{Cl}_{2} \mathrm{Si}(\mathrm{OTf})_{2}$ or $\mathrm{Hf}(\mathrm{OTf})_{4}$. Tetrahedron Lett. 2002, 43, 6391-6394.

12. Ke, H.Z.; Chen, H.K.; Simmons, H.A.; Qi, H.; Crawford, D.T.; Pirie, C.M.; Chidsey-Frink, K.L.; Ma, Y.F.; Jee, W.S.; Thompson, D.D. Comparative effects of droloxifene, tamoxifen, and estrogen on bone, serum cholesterol, and uterine histology in the ovariectomized rat model. Bone 1997, 20, 31-39.

13. McDonnell, D.P. The molecular pharmacology of SERMs. Trends Endocrinol. Metab. 1999, 10, 301-311. 
14. Lonard, D.M.; Smith, C.L. Molecular perspectives on selective estrogen receptor modulators (SERMs): Progress in understanding their tissue-specific agonist and antagonist actions. Steroids 2002, 67, 15-24.

15. Jordan, V.C. Antiestrogens and selective estrogen receptor modulators as multifunctional medicines. 2. Clinical considerations and new agents. J. Med. Chem. 2003, 46, 1081-1111.

16. Shiina, I.; Suzuki, M.; Yokoyama, K. Short-step synthesis of tamoxifen and its derivatives via the three-component coupling reaction and migration of the double bond. Tetrahedron Lett. 2004, 45, 965-967.

17. Shiina, I.; Sano, Y.; Nakata, K.; Suzuki, M.; Yokoyama, T.; Sasaki, A.; Orikasa, T.; Miyamoto, T.; Ikekita, M.; Nagahara, Y.; Hasome, Y. An expeditious synthesis of tamoxifen, a representative SERM (selective estrogen receptor modulator), via the three-component coupling reaction among aromatic aldehyde, cinnamyltrimethylsilane and $\beta$-chlorophenetole. Bioorg. Med. Chem. 2007, 15, 7599-7617.

18. Sano, Y.; Shiina, I. Short-step synthesis of droloxifene via the three-component coupling reaction among aromatic aldehyde, cinnamyltrimethylsilane, and $\beta$-chlorophenetole. Tetrahedron Lett. 2006, 47, 1631-1635.

19. Sano, Y.; Nakata, K.; Otoyama, T.; Umeda, S.; Shiina, I. An expeditious synthesis of lasofoxifene and nafoxidine via the novel three-component coupling reaction. Chem. Lett. 2007, 36, 40-41.

20. Shiina, I.; Sano, Y.; Nakata, K.; Kikuchi, T.; Sasaki, A.; Ikekita, M.; Hasome, Y. Synthesis of the new pseudo-symmetrical tamoxifen derivatives and their anti-tumor activity. Bioorg. Med. Chem. Lett. 2007, 17, 2421-2424.

21. Shiina, I.; Sano, Y.; Nakata, K.; Kikuchi, T.; Sasaki, A.; Ikekita, M.; Nagahara, Y.; Hasome, Y.; Yamori, T.; Yamazaki, K. Synthesis and pharmacological evaluation of the novel pseudosymmetrical tamoxifen derivatives as anti-tumor agents. Biochem. Pharmacol. 2008, 75, 1014-1026.

22. Nagahara, Y.; Shiina, I.; Nakata, K.; Sasaki, A.; Miyamoto, T.; Ikekita, M. Induction of mitochondria-involved apoptosis in estrogen receptor negative cells by a novel tamoxifen derivative, Ridaifen B. Cancer Sci. 2008, 99, 608-614.

23. Kumar, S.; Kumar, V.; Chimni, S.S. Novel indium-mediated ternary reactions between indole-3carboxaldehydes-allyl bromide-enamines: facile synthesis of bisindolyl- and indolyl-heterocyclic alkanes. Tetrahedron Lett. 2003, 44, 2101-2104.

24. Roy, U.K.; Jana, P.K.; Roy, S. $\mathrm{Pd}^{0} / \mathrm{Sn}^{\mathrm{II}}$ mediated three-component cascade coupling (3-C $\left.\mathrm{C}^{3}\right)$ approaches. Tetrahedron Lett. 2007, 48, 1183-1186.

25. Zhao, X.-L.; Liu, L.; Chen, Y.-J.; Wang, D. Three-component Barbier allylation, Friedel-Crafts alkylation and intramolecular hydroalkoxylation in an ionic liquid for the direct synthesis of 4arylchromans. Synlett 2007, 9, 1357-1364.

26. Zhao, X.-L.; Liu, L.; Chen, Y.-J.; Wang, D. Three-component Barbier allylation-Friedel-Crafts alkylation promoted by $\mathrm{BuPyCl} / \mathrm{SnCl}_{2} \cdot 2 \mathrm{H}_{2} \mathrm{O}$ : Application to the synthesis of 4-(substituted phenyl)chromans. Chin. J. Chem. 2007, 25, 1312-1322.

27. Ke, H.Z.; Qi, H.; Crawford, D.T.; Chidsey-Frink, K.L.; Simmons, H.A.; Thompson, D.D. Lasofoxifene (CP-336,156), a selective estrogen receptor modulator, prevents bone loss induced by aging and orchidectomy in the adult rat. Endocrinology 2000, 141, 1338-1344. 
28. Gennari, L.; Merlotti, D.; Valleggi, F.; Martini, G.; Nuti, R. Selective estrogen receptor modulators for postmenopausal osteoporosis - Current state of development. Drugs Aging 2007, 24, 361-379.

29. De Lorenzo, M.S.; Alonso, D.F.; Gomez, D.E. Nafoxidine modulates the expression of matrixmetalloproteinase-2 (MMP-2) and tissue inhibitor of metalloproteinases-1 (TIMP-1) in endothelial cells. Anticancer Res. 2000, 20, 395-400.

30. Lednicer, D.; Babcock, J.C.; Lyster, S.C.; Duncan, G.W. Derivatives of 1,2-diphenyl-3,4dihydronaphthalene as antifertility agents. Chem. Ind. (London) 1963, 408-409.

31. Lednicer, D.; Lyster, S.C.; Aspergren, B.D.; Duncan, G.W. Mammalian antifertility agents. III. 1Aryl-2-phenyl-1,2,3,4-tetrahydro-1-naphthols, 1-atyl-2-phenyl-3,4-dihydronaphthalenes, and their derivatives. J. Med. Chem. 1966, 9, 172-176.

32. Lednicer, D.; Lyster, S.C.; Duncan, G.W. Mammalian antifertility agents. IV. Basic 3,4dihydronaphthalenes and 1,2,3,4-tetrahydro-1-naphthols. J. Med. Chem. 1967, 10, 78-84.

33. Lednicer, D.; Emmert, D.E.; Lyster, S.C.; Duncan, G.W. Mammalian antifertility agents. VI. A novel sequence for the preparation of 1,2-disubstituted 3,4-dihydronaphthalenes. J. Med. Chem. 1969, 12, 881-885.

34. Cameron, K.O.; Jardine, P.A.D. Preparation of 5-[4-(2-heterocyclylethoxy)phenyl]-5,6,7,8tetrahydronaphthalene-2-ols and 1-[4-(2-heterocyclylethoxy)phenyl]-6-hydroxy-1,2,3,4-tetrahydroisoquinolines as estrogen agonists/antagonists. WO9621656, 1996; [Chem. Abstr. 1996, 125, 195446].

35. Rosati, R.L.; Jardine, P.D.; Cameron, K.O.; Thompson, D.D.; Ke, H.Z.; Toler, S.M.; Brown, T.A.; Pan, L.C.; Ebbinghaus, C.F.; Reinhold, A.R.; Elliott, N.C.; Newhouse, B.N.; Tjoa, C.M.; Sweetnam, P.M.; Cole, M.J.; Arriola, M.W.; Gauthier, J.W.; Crawford, D.T.; Nickerson, D.F.; Pirie, C.M.; Qi, H.; Simmons, H.A.; Tkalcevic, G.T. Discovery and preclinical pharmacology of a novel, potent, nonsteroidal estrogen receptor agonist/antagonist, CP-336156, a diaryltetrahydronaphthalene. J. Med. Chem. 1998, 41, 2928-2931.

36. Chu, C.K.F. Preparation of cis-1-[2-[4-(6-methoxy-2-phenyl-1,2,3,4-tetrahydronaphthalen-1yl)phenoxy]ethyl]pyrrolidine as intermediate for antiosteoporotic agent. JP2000327670, 2000; [Chem. Abstr. 2001, 134, 4858].

37. Edstrom, E.D.; Livinghouse, T. New methods for the generation of episulfonium ions. An application to the synthesis of carbocycles via sulfenium ion promoted arene-alkene cyclizations. J. Am. Chem. Soc. 1986, 108, 1334-1336.

38. Edstrom, E.D.; Livinghouse, T. On the direct generation of episelenonium ions from alkenes. An efficient new procedure for effecting selenylative arene-alkene carboannulations. Tetrahedron Lett. 1986, 27, 3483-3486.

39. Barluenga, J.; González, J.M.; Campos, P.J.; Asensio, G. I(Py $)_{2} \mathrm{BF}_{4}$, a new reagent in organic synthesis: General method for the 1,2-iodofunctionalization of olefins. Angew. Chem. Int. Ed. 1985, 24, 319-320.

40. Barluenga, J.; González, J.M.; Campos, P.J.; Asensio, G. Iodine-induced stereoselective carbocyclizations: A new method for the synthesis of cyclohexane and cyclohexene derivatives. Angew. Chem. Int. Ed. 1988, 27, 1546-1547. 
41. Appelbe, R.; Casey, M.; Dunne, A.; Pascarella, E. Stereoselective synthesis of tetralins using cationic cyclisations. Tetrahedron Lett. 2003, 44, 7641-7644.

42. Homsi, F.; Robin, S.; Rousseau, G. Preparation of bis(2,4,6-trimethylpyridine)iodine(I) hexafluorophosphate and bis(2,4,6-trimethylpyridine) bromine(I) hexafluorophosphate. Org. Synth. 2000, 77, 206-208.

43. Bindal, R.D.; Durani, S.; Kapil, R.S.; Anand, N. Utility of 4-trimethylsiloxyphenylmagnesium bromide in grignard reactions. Synthesis 1982, 405-407.

Sample Availability: Available.

(C) 2010 by the authors; licensee MDPI, Basel, Switzerland. This article is an open access article distributed under the terms and conditions of the Creative Commons Attribution license (http://creativecommons.org/licenses/by/3.0/). 